\title{
軽水炉発電プラントの水化学技術
}

\section{Water Chemistry Technology of LWR Nuclear Power Plants}

石榑 顕吉, 水野 孝之, 檑 孝二,

天野 治, 西村 健, 直并 洋介, 長尾 博之, 内田 俊介, 笠原 和男, 阿部 堅司, 立川 圆造

\author{
（1991年 10月12日 受 理）
}

\begin{abstract}
軽水师ブラントの水化学技術は，材料と水環境の相互作用を报う技郝であり，その改善や技術の 向上が，わが国の軽水炬プラントの高稼做率や従業員の被懪低隇に大きく貢献してきている。いま キ，その技政は世界のトッブレベルにある。

本「特集」では, 水化学技術の変遷, 高温水化学に関する基盤技術,ブラント水化学に関する要素技 划と成果および今後の課題について，それぞれの分野で活唯されている方々に易しく解説して頂い た。

（担当編集委員・中島宣雄）
\end{abstract}

I. 水化学技術とは

I . 基盤技術はどこまで焦歩したか

II. 実機プラントの水化学管理技術
IV. 要素技術の開発

V. 水化学の将来展望

\section{I. 水化学技術とは}

\section{1.はじめに}

過去20年以上に及心゙軽水妒の運転経験が，原子力発 電ブラントに和ける水化学管理の重要性に対する認識 を深めてきた。軽水炉はこれまで，種々のトラブルを 程験してきたが，その中には水化学技術が関与するも のも少なくない。例光ば，加圧水型原子力発電ブラン ト(PWR) 蒸気発生器 (SG) の腐食トラブルや沸滕水 型原子力発龟ブラント(BWR) 配管の応力腐食割れ (SCC)，配管線異率の上年による従業員被曝の増大な どである。このようなトラブルが発生するたびル，そ の解決のため照命の努力を重ねてきた結果，水化学技 術は近年著しく進展し，従業員被懪の低減なぞで大き な成果が得られるに至った。

本「特集」においては，水化学技術がこれまでに果た してきた役割と，その発展によって得られた成果を紹 介するととるに，今後一層の技術の高度化に向けて達 成すべき課題を考える。

\section{2. 水化学技術の役割}

水冷却妒ではその名の通り，原子炉の命却材として 水を使用して出り，原子炉を安全にから効率よく運䢂 するために，冷却水は化学的に充分管理されなければ ならない。このための技術を“水化学技術”，またその 技術のよりどころとなる科学基盤を“水化学”と呼んで いる。原子炉冷却水の水化学管理の目的は以下の通り てある。

(1) 配管線量率の低減

(2) 機器·配管の信頼性の向上

（3）然料被覆管の健全性の稚持

（4）放射性廃較物発生量の低減

プラントの運転年数の増大に伴って，冾却和配管の 線量率が次第に増大する傾向が見られ、これは発電所 における従業員被曝の增大をむたらす。原子力発電ブ ラントの従業員被曝の大部分は，定期検查時に作業員 が機器や配管に接近する際に受けるるのである。した がって，配管等の線量率低減は從業員被䀧の低減につ 
ながり，世界各国ともこの問題を重要視し，そのため の技術開発が活発に進められている。配管線量率の低 減は，水化学管理たけでなく材料面からの対策も含め て総合的行われるべきのであるが，水化学管理の 果たす役割は極めて大きい。

軽水妒は，すでに述べたよらに材料の腐食に起因す るトラブルを多く経耠した。腐食は材料と環境の相互 作用の結果として誘起されるるのであるから，材料倒 からのフプローチる重要であるが，村料の交換が不可 能でちったり程済的でない場合，あるいは材料面での 対策に加える裕度として，水化学管理の重要性が增大 している。

近年，わが国汅括ける然料被覆管の品質の向上は著 しく，原子炉運転中に和ける然料破椇に上る 万P(核分 致生成物)リークの発生は大幅に低減している。その ため水化学管理面における然料被㠅管に対する配虑は 必ずしる重要な地位を占めるるのでなかった。しかし 最近，浜岡 1 号機で発生したジルカロイ被覆管の腐食 事例や米国ミルストン 1 号炬の高 $\mathrm{pH}$ 運転時に括ける
被覆管の腐食举動は，改めて被覆管腐食に対する水化 学管理の重要性を再認識させることとなった。今啳, 軽水妒に打燃料の高然焼度化が進められる中でその 重要さは增するのと考えられる。

原子力発電ブラントで発生する放射性䧹亲物の発生 量低減は，極めて重要なテーマであるが，従来水化学 管理の直接の目標でなかった。しかし，亦化学管理は 放射性廃童物のソースである放射性核種の生成低減を 目指して括り，さらに冷却水の净化に付随して多量の 廃亲物が発生するので, 水化学管理は, 前記(1) (3)の 目標を達成するばかりでなく，廃裹物量の低隇をる目 指するのとなっている。

過去10年以上にわたる水化学技術開発はすでに大き な成果をすたらしている。第I-1四に，わが国に打け る原子力発電所の従業員被懪の推移を示す。BWRの 場合，1978年をビークとし，過去10年間に被懪量は著 しく低減している。特に最近稼動を開始した新設ブラ 、ントに怙いてその效果は目覚ましいるのがあり，世界 的にも高く評価されている。

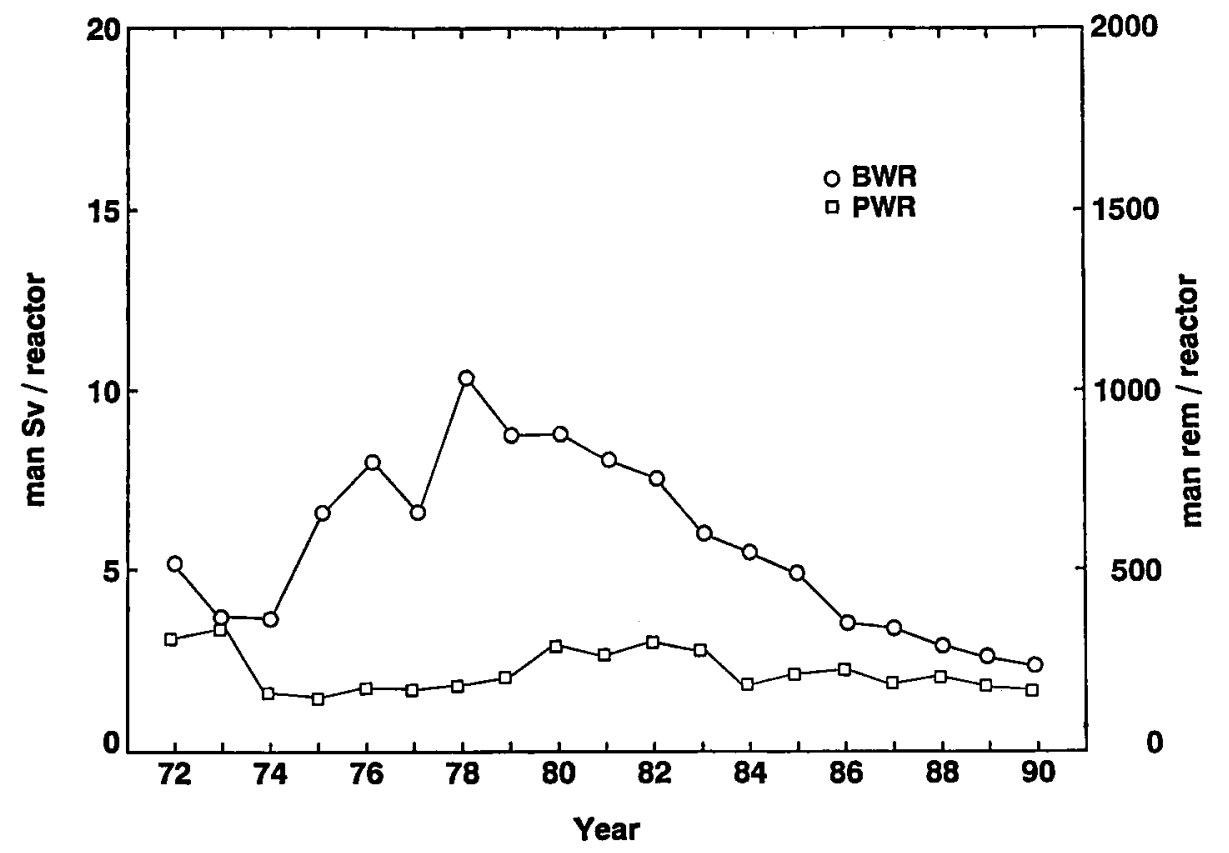

第 1-1図 日本の原子力発電ブラントにおける平均被曝線量の推移

\section{3. 水化学技術の特色}

水化学技術のこれまでの発展の経緯を見ると，原子 カ発電ブラントでトラブルが発生するたびにその原因 の究明と対策に追われこれを一つ一つ克服してきた
ことが成果として現れているといらのが実情で，いわ ばトラブル・シューティンク的なフブローチを求めら れる問題解決型の技術であった。研究開発がトラブル の発生ととるにスタートし，その解決によって終わる パターンの綝返しでは,どうしてすつぎはぎ的印象を 
ま奴れがたく，総合的視点に欠ける面があったこと は否めない。

水化学技街の難しさは，原子炉冷却系には数多くの 材料が使用されて招り，これらの材料が椧却水と接し ている環境条件が少しずつ異なっている点にある。確 かに循環している水は共通であるが，温度，流速，材料 の形状，沸滕の有無，放射線場の有無などの策件が位置 によって異なって招り，その結果各村料に対する化学 環境もおの拈の異なったるのとなっている。問題を引 き起こす腐食の種類にしても，全面腐食，隙間腐食，孔 食，応力腐食，エローションンコロージョンなど実化多 種多様である。したがって一つの材料の一つのトラブ ルの解決策が同じ材料の他のトラブルを誘起したり, 他の材料の新たなトラブルの原因になりかねないとい ら問題をかかえている。このため，一方で酸素を添加 しながら，他方でこの酸素を除くために水素を添加す るなどといら一見極めて理解し難い手法の選択も起り 得る。

これまでの水化学技術分野に打ける活発な研究開発 はこの技術を多様化する結果をもたらした。例觉ば， 配管線量率を低減する手洗としても，浄化系の性能向

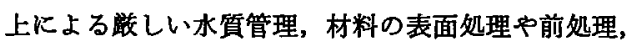
種ふの除染法など多様化した技術オブションが用意さ れており，その選択の幅は広がっている。したがっ て，システム全体を考虑し，総合的視点供ゔいて技 術の最適化を行なっていくことが重要となっている。

これまでの運転経験に基つくく水化学管理の重要性に 対する認識から，新たに水化学管理基準を作成しょう といら動きがある。従来各ブラントにはブラントの形 式によって定められた办質仕様が存在したが，この仕 様は運転経験の浅い時期に設定されたすので，最近の 運転状況とは合わなくなって括りこれを見直そら との考えに基ついている。すでに米国の電力研究所 (EPRI)は独自の水化学ガイドラインを設定し始めて 㧍り，IAEA むこれに類似したものを作りたいとの意 向があると聞く。

このよらな技術の基準化，統一化はその技術が成欮 期にあることを示するので，その技術の重要性の認識 を広める上では極めて重要である。しかし，各国の運 転経駼护㭪水準の相遠により，このよらな技術基準 のるつ意味も異なるるのと思われる。またこの上らな 技術の基準化の方向は，上述の技術の多様化の方向之 は逆行する面を持っものでるある。すで技術の基淮 化の時代は過ぎ，今後多様化の時代に向からと予想さ れるわが国に抋いて，現時点で水化学ガイドラインを
設定することは，必ずしむ時宜を得たるのでないよう に著者には思われる，

\section{4. 技術の動向}

1 次系における水化学管理の考光方は，これまで PWR と BWR で異なっていた。BWRでは妒心で沸㖒 があるため不揮発性の添加物による制御は困難であ り，不純物を徹底的に除去することが重要と考えられ てきた。そのため復水脱塩器の性能向上を図り，給水 系への酸素注入を行なって炉心へのFeの持込みを低減 することに努力が傾注された。っいかながら，Fe レべ ルの低隇は相対的にNi レベルの增大を招き，その結 果，炉水中の ${ }^{80} \mathrm{Cop}{ }^{58} \mathrm{Coが}$ 上昇する現象が認められた。 $\mathrm{Fe}$ の持込みを抑制するばかりでなく， Ni/ $\mathrm{Fe}$ 比を制御 することが必要と考光られ，現在日本の多くのBWR プラントでは，徽量のFeを注入して給水系の制御を行 なっている。これをさらに一歩進めたすのが米国で開 発された給水系への Zn 注入である。Zn注入によって 安定な腐食皮膜が形成され，放射性 $\operatorname{Coの}$ 皮膜中への取 込みが抑制されると説明されている。Zn注入はBWR ばかりでなく，PWRに打いても有効であるとの試験 結果が最近報告されて，Zn注入に関心が高まってい る。

BWRステンレス鋼配管のSCCが大きな問題となっ たことは未だ記憶に新しいが，その水化学面での対策 として給水系への水素注入が米国やスウェーデンのブ ラントで次第に定着しつつある。しかす単に再循謤配 管のSCC 対策にとどまらず，炬心まわりの腐食環宪の 楥和をむ狙いとしたるのとなっている。他方，この水 素注入は配管線量率の上界という面で，必ずしす好ま しくない効果を生して沏り，今後この効果が過渡的な 現象であるかどうか見届ける必要があるう。

PWRの 1 次系では沸滕がないので，添加物を加克 て水化学制御を行ら方式がとられてきたが，最近との $\mathrm{pH}$ 制御を更に精密に行うことが必要であると考えら れている。従来は $3000^{\circ}$ Cて $\mathrm{pH}=6.9 \pm 0.2$ となるように 制御するのが腐食生成物(CP)の移行を抑制する上で 良いとされてきたが，最近ではさらに高い $\mathrm{pH}$ (7.3〜 7.4)での運転が好ましいとされている。しかしなが ら，この高いpH での運転が燃料被覆管の腐食を加速 する可能性やSG イン ンネル伝熱管の 1 次側における SCCを促進するとの試験結果む報告されており，真化 最適の $\mathrm{pH}$ がいくつであるかについて未だ結論が得ら れていない。

上述のようK，最近ではBWR,PWRいずれの場合も 
1 次系の制御を添加物によって行う方向で一致してき ており，一層正確で精密な制御が求められている。

PWRのSGの腐食トラブルは, 改善の方向に向かっ てはいるすのの，いまなお世界各国のブラントで発生 している。SG 2 次側の伝熱管腐食の問題は，運転経験 のそしかった初期に採用されたリン酸ソーダによる水 化学処理が不適切であったことから始まっており，り ン酸ソーダ処理はその後フンモニてとヒドラジンによ る全揮発性処理(AVT)に切り換えられた。リン酸り 一ダは沸滕によりフルカリ港縮を引き起して問題とな った。アンモニては沸滕により気相へ移行するので浱 樎は起らないが，逆に移行量が多過ぎ夜相の $\mathrm{pH}$ が低 下することが問題となっている。そのため沸滕による 移行量の少ない有機了ミンによる処理が検討され，千 ルフォリン処理を採用するブラントがフランスや米国 で増えている。2次系においてるより精度の高い水化 学制御を求めてな摸索中というのが現状である。

\section{5. 今後の課題}

すでに速へたように，水化学技術はこれまで1次系 の線量低减と機器・配管の種々の腐食トラプルの解决 を主たる目漂とする問題解決型の技術であった。その ためどらしてるシステム全体を見通した上で最適化 を図るといら総合的視点にやや欠けるきらいがあっ た。

またトラブルに対応する仕方も，当初Fe持ち込み低
減を徽底的に行らとか, $\mathrm{pH}$ の值を一定にするという ように技術の基準化·画一化を求める方向で進んでき た。

他方，最近の水化学技術の進展は技術の高度化と合 わせて多様化をるたらした。不純物を一層敩しく除去 することは共通的な課題であるが，この他にも目標を 達成するための技術が数多く用意され，その選択肢の 幅が大きく広がっている。このよらな状況の中で必要 なことは，プラントに最む適したオブションを選択す ることである。各ブラントには材料・設計などの面で， そのブラント固有の特徽とそれぞれ異なった運転展歴 があり，これらの特色に配虑した対応が考えられなけ ればならないであるら。

しかしながら，水化学技術の現状を見ると、ブラン トに合った技術の最適化を行いらるだけの指道原理を 有しているとはいい難いのが央情である。これを行ら ためには，冷却系で生起する現象の基碄的な理解をさ らに深める必要があり，その基礎となるブラントにお。 ける水化学データのより正確な把握と, 現象のメカ二 ズムを理解するための科学基盤の強化とが必要であ ろら。

今後一層の従業員被曝の低減と，然料系を含めた機 器配管の信頼性向上を図る努力を続ける必要がある が, さらに長期的な視野に立って, 機器やブラントの 長寿命化を目標とした予防保全型あるいは問題予測型 の技術に転換していくことが望まれる。

\section{II. 基盤技術はどこまで進歩したか}

\section{II-1 高温の水はどんな性質 を持っているか}

三重大学 水野孝之

\section{1. 水の特翼性}

水は地球上に最す豊富に存在する物質であるが，そ の物理化学的性質には，多くの物質に比べて非常に特 異なるのがある。例光ば，熟容量が大きいので，熱媒 体として好適であり，広く使用されている。また，分 子量が小さい㓶りには常温で液体であること，誘電率 が大きく電解質を良く溶解すること，ならびに本自体 る一部解離していること等の特徽がある。これらは, 水分子は酸素を中心に 2 つの水素が $104.3^{\circ}$ の角度で結
合しているため，極性が強く，水分子間の水素と酸素 の間で水素結合が形成されていることに起因してい る。

\section{2. 水の特異性の温度依存性}

水分子が水素結合している分子数は，第 I-1(1)图 に示すように，常温付近では70\%の水分子が 4 つの水 分子と水素結合し，承と同し結晶構造である 4 配位座 の四面体を形成している(1)。しかし残りの30\%は水素 結合数が 3 以下と少なく結晶棈造を形成し得ないの で, 全体として液体化している。このように大半が氷 の構造を持つことる，水が特異性を示す大きな要因で あるが，温度が上昇すると分子の運動が活発になり， 第 I-1(1) 图のよ5に，4配位座の四面体棈造は直線的 に減少していき, 水の特異性は少なくなって行く。 


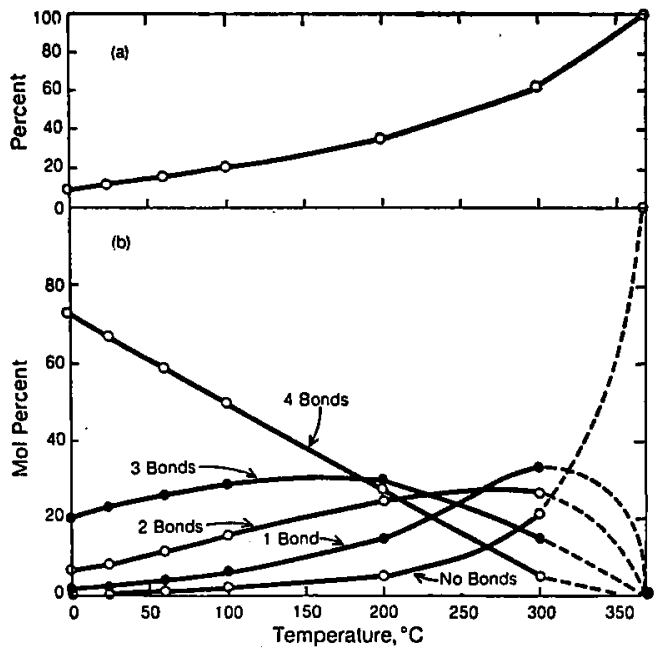

(a)切断された水素結合数の割合

(b) $0 \sim 4$ の水素結合を持つ水分子の割合

第 I-1(1) 図 水中の水素桔合数の温度依存性 (Haggisらによる計算值(1)

水の特性として, ここでは水化学の観点から重要な 水の誘電率と解離定数について温度の影䇾を述べ。

(1) 誘電事：常温に招ける水の誘電率は多くの有 機溶媒に比べて数倍から 1 析大きく，特異な液体に属 する。しかし温度上㫒とともに，第 I-1(2) 图に示すよ うに，誘奄密は急速に低下し(2)，200 付近ではメタ， ールと，300゚ではフセトンと，さらに臨界点付近で はクロロホルムやェチルェーテルと同度まて下が り，水の特異性はほとんどなくなる。

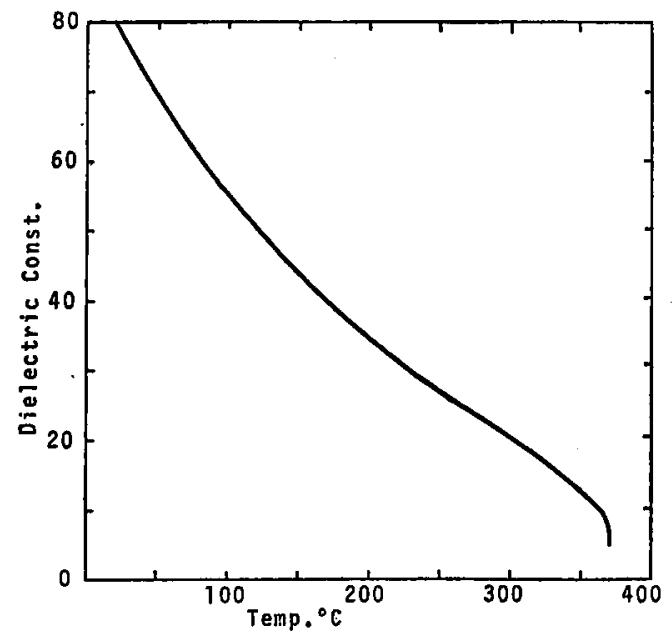

第 I-1(2)图水の誘電率の温度依存性
(2) 解離定数： 水の解離定数 は250 り， $\mathrm{pH}$ 等水溶液系の化学特性のベースになっている。 これる温度上昇とともに变化するが，単純ではない。 解離定数 $\left(K_{w o}\right)$ と純水の $\mathrm{pH}$ の関係は， $K_{v o}=10^{-2 \times p \mathrm{~B}}$ で 表わされる。螕和蒸気压では pH として，第 I-1(3) 图 に示すよらに, $250^{\circ} \mathrm{C}$ を゙は温度上昇とともに水は解 㽫し易くなり(3)，水の $\mathrm{pH}$ (中性)は5.6，すなわち水素湜 度としては常温の約30倍に増加する。それ以降は逆に 解離し難くなり，372 $\mathrm{C} て ゙$ 常温と同一の解離定数にな る。その後さらに急減し, 臨界点 $\left(374.15{ }^{\circ} \mathrm{C}, 22.120\right.$ $\mathrm{MPa}$ )では解離定数は常温より2析小さい $10^{-10}$ にな る。これは常温のメタノールと同程度の值である。こ のよらК $\mathrm{pH}$ は中性であるが, 水素イオン濃度は大き く変わる。特に $250^{\circ} \mathrm{C}$ 以下での水素イオン湦度の增加 が水の化学的特性にどのように影響するかは，水化学 の観点からは重要であるが，現在のところほとんど究 明されていない。

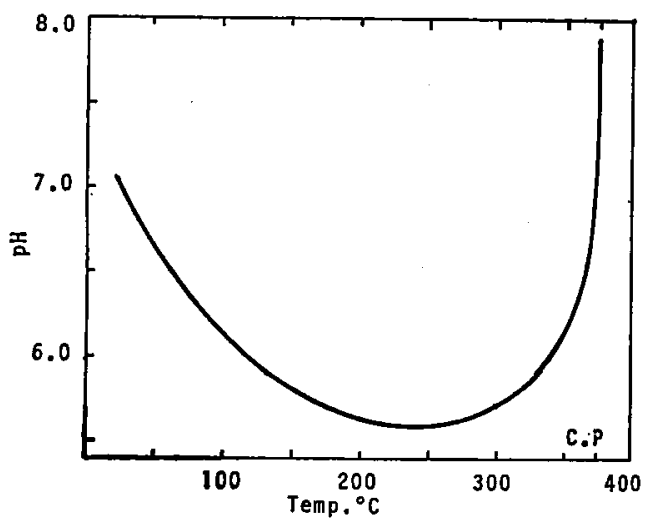

第 I-1(3) 図水のpH(中性)の温度依存性

一方，密度を常温と同じ $1 \mathrm{~g} / \mathrm{cm}^{\mathrm{g}}$ になるように相当

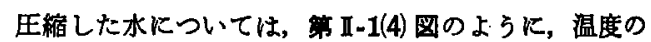
逆数と解離定数の対数をプロットとすると, 1,000 C まで直線関係が得られ(4), 解離定数は温度上昇ととす に增加することがわかる。これによると，950付近 では办の解離定数は $10^{-7}$ とい5大きな值になり，5 $\mathrm{mmol} / \mathrm{l}$ の蕞度の酢酸水溶液(常温)と同じ水素イオン 浱度になる。このように温度上昇に伴う密度低下を排 除すると単純化され, 温度が水の解離を促進すること がよくかかる。

\section{3. 溶存イオンの熱力学特性}

温度上昇とともに水の蒸気圧す増加するので，高温 水中に特ける腐食反応やスケール成分の析出等水化学 


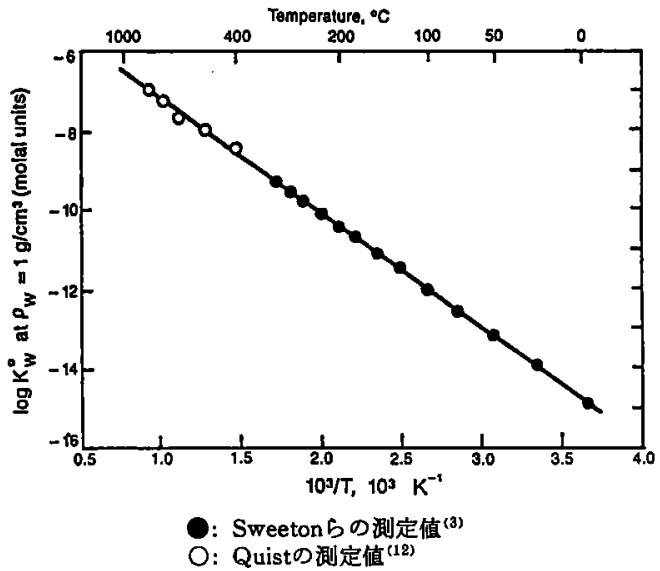

第 1-1(4) 図定密度 $\left(1 \mathrm{~g} / \mathrm{cm}^{8}\right)$ の水の 解離定数の温度依存性

の分野で重要な性質を直接分析測定することは極めて 困難である。現在のところ，高温水溶液の直接の物性 湘定手段としては，電気化学的な手法で可能な電気伝 導率と電極電位の湘定に限られているといえる。これ らのデータを有効に活用し，高温水溶液の物性をでき る限り広範囲に推定するためには，データを上手に解 析して，応用範囲の広い一般則を諉導することが必要 である。

一般に熱力学的には化学反応の方向や起こり易さの 目安として, Gibbsの自由エネルギ一变化 $\Delta G(T) か ゙$ 使 用されている。これは熱力学的には温度の関数として (1)式のように与えられており，常温でのデータに加 えて定圧熱容量が温度の関数で求められていれば, 計 算できることになる。

$$
\begin{aligned}
& \Delta G^{0}(T)=\Delta G^{0}(298)-\Delta S^{0}(298)(T-298) \\
& +\int_{29 \theta}^{T} \Delta C_{p}{ }^{0} d T-T \int_{298}^{T} \Delta C_{p}{ }^{0} d \ln T \\
& \text { ここで， } \Delta S^{0}(298): 25^{\circ} \mathrm{C} \text { た打る標準エントロ } \\
& \text { ピーの差 } \\
& \Delta C_{p}{ }^{0} \text { ：モル定圧熱容量(比熱)の差 }
\end{aligned}
$$

安定な元素分子ゃ化合物については，この温度関数が ヘンドブック等に揭載されている。しかし，本溶液反 応では不可欠なイオンについては皆無に近い状熊であ るので, 推定方法の開発が重要な課題になっている。

(1) Correspondence Theory (対応原理)

高温水中のイオン種の熱力学データを算出する怪験 式を最初に提案したのがCriss とCobble 年にCorrespondence Theory として提案された。これ は，200゚までのエントロピーの測定データを解析し た結果，エントロピーとして絶対エントロビーを用い
ると，常温のエントロピーと $200{ }^{\circ}$ Cのエントロピーと の間にはイオン種を適切に分類することにより，直線 関係があることを見出したものである。平均定王熱容 量は $2 つ の$ 温度のエントロピーより算出される。Criss らはこれを $300{ }^{\circ}$ まで外挿できるとして経験式を提案 した。これ以降，この式を用いて高温での電位-pH図 が各種の金属について作成され，腐食研究に活用され るよらになった。

しかし, 最近高温水中の塩類の熱力学データが充実 され、これらとCorrespondence Theoryによる計算值 と比較吋ると, $200^{\circ} \mathrm{C}$ 以上特に $250^{\circ} \mathrm{C}$ 以上で相当大きな 乘離があることがわかり，計算式の見直しが図られて いる(6)。

(2) Principle of Balance of Identical Like Charges (Isocoulombic Reactions)

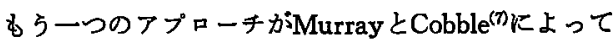
見出された熱容量についての“Principle of Balance of Identical Like Charges”と，同時に発表されたLindsay， $\mathrm{J}$. ${ }^{(8)}$ の解離反応についての“Isocoulombic Reactions”で ある。これは腐食抑制やスケール生成抑制の鍵となる $\mathrm{pH}$ 算出するのに有効な释験則である。酸・塩基や塩 の解離反応は, 通常 (2)式の上うに中性の分子が陽イ オンと陰イオンに解離する式で表わされ，解離定数す これを基に表示されている。

$$
A B(\mathrm{aq})=A^{+}(\mathrm{aq})+B^{-}(\mathrm{aq})
$$

しかし，この場合には中性分子からイオンが生成する が，中性分子とイオンでは溶媒水分子との相互作用が 大きく異なる。またこの相互作用,水和に関与する 水の物性, 例えば誘電率等は前述のように温度の影警 を強く受ける。このため（2 ）式のような解離反応で

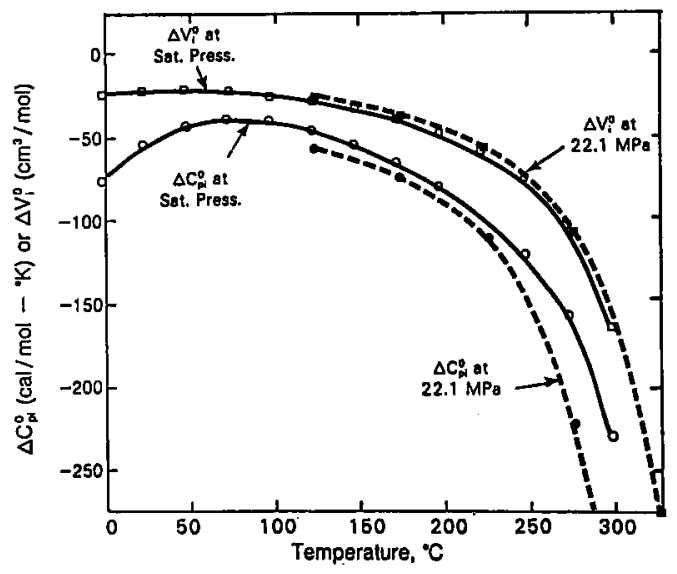

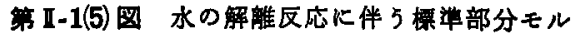
熟容量と栖算部分モル容皘の变化 


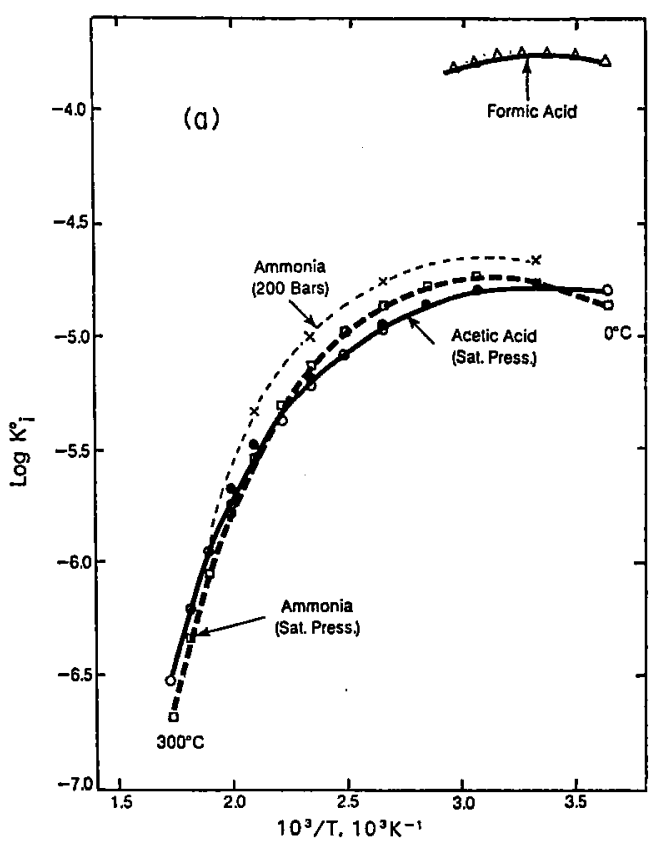

(a) イオン解離反応

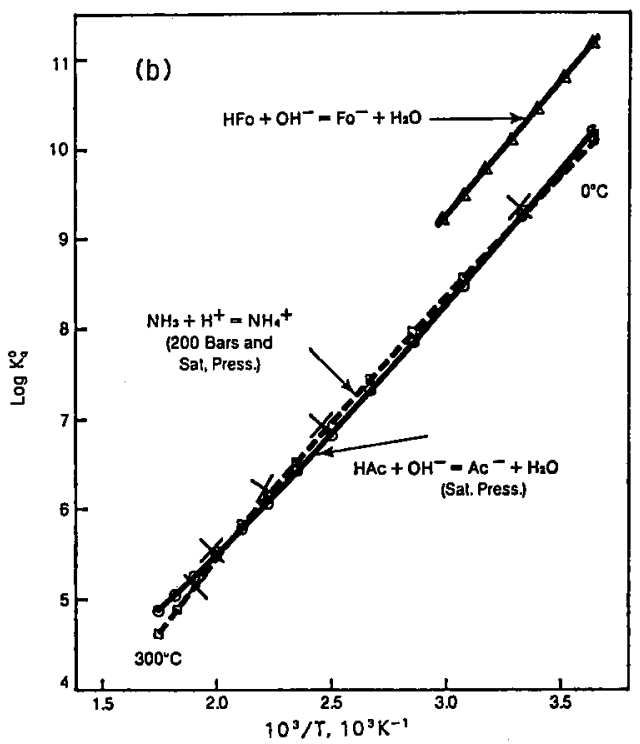

(b) Isocoulombic equations

第 I-1(6) 図 フンモニア,醀酸, ギ酸の解離定数の温度佬存性

は反応に伴う熱容量や比容積の変化が大きくなる。こ の 1 例として, データが整備されている水の場合, 第 I-1(5) 図の上5に, 熱容量や比容積が $200{ }^{\circ} \mathrm{C}$ 以上で 大きく変動することがわかる(9)。実際に(2)式による 解離定数の温度依存性は第 I-1(6) 図(a)(フンモニフ)の ように曲線になるめ。

Principle of Balance of Identical Like Charges で は,このイオンと水分子の相互作用をキャンセルし， 温度の影稫を少なくするため, 反応式の両辺の電荷が 等しくなるよらに固き換えて，解離定数を定義したる のである。例えば, アンモニアの場合には（3)式のよ うに表わされる。

$$
\mathrm{NH}_{3}(\mathrm{aq})+\mathrm{H}^{+}(\mathrm{aq})=\mathrm{NH}_{4}{ }^{+}(\mathrm{aq})
$$

このようにして定義した解離定数の温度依存性を調べ ると，第 II-1(6) 図(b)のように，300兄まで直線関係が 得られることがわかった呂これは弱酸, 弱塩基だけ でなく，强酸や塩類にす相当適用できることが示され ている(11)。この経験則を応用することにより，湘定 データが低温付近に限られているイオン種についても 高温水中の解離挙動を相当精度よく推定することが可 能である。

\section{4. 沸滕現象とスケール生成}

腐食生成物(CP)の放射化や腐食性不純物の溜縮等
の主原因となる然料棒へのクラッドの堆積は重要な課 題であるが，これには沸腾現象が密接に関与してい る。この沸騰現象す表面張力等の温度体存性と関連し て温度の影響を受け，第 I-1(7) 図に示すように，温度 上昇とともに発生する気泡の径は減少するが，逆に発 泡点の密度は増加して, 蒸発量が維持されている(12)。 一方, クラッドは発泡点に優先的に推積し, 推積初期 には斑点状のスケールを生成するが，その斑点の径は

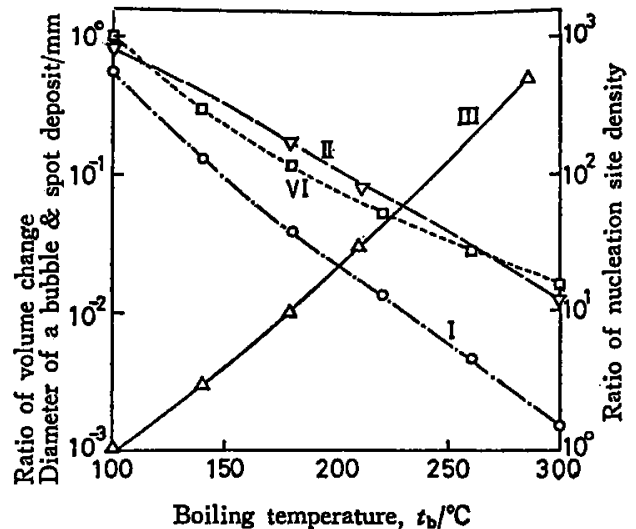

觜隹東 $: 700 \mathrm{~kJ} /\left(\mathrm{m}^{2} \cdot \mathrm{s}\right)$

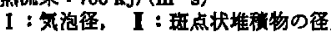

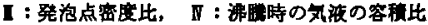

第 I-1(7) 图 沸滕特性への的包温度の影蟹 
気泡の径の減少と同様に低下し，スケールの点密度 は增加する。スケール堆積量については，気泡の径と 気泡点密度が交差する $200{ }^{\circ} \mathrm{C}$ 付近で最低となりこの 前後でクラッド堆積機構が変化するよらである。

\section{一考文献一}

(1) Haggis, G.H., Hasted, J.B., Buchanan, T.J.: J. Chem. Phys., 20, 1452 (1952).

(2) Japan Soc. Mech. Eng.: "1980 JSME Steam Table in $S I^{\prime \prime}$, (1980), JSME.

(3) Sweeton, F.H., MEsmer, R.E., BAes, C.F.: $J$. Solution Chem., 3, 191 (1974).

(4) Marshal, W.L., Frank, U.K.: J. Phys. Chem. Ref. Data, 10, 295 (1981).
(5) CRISS, C.M., CobBle, J.W.: J. Am. Chem. Soc., 86, 5385; 5390 (1964).

(6) CRIss, C.M.: Proc. 41 st Int. Water Conf. Engineer's Soc., Western Penn., 311 (1980).

(7) Murray, R.C., Cobble, J.W.: ibid., 295.

(8) LINDSAY, W.T., Jr.: ibid., 284.

(9) CoHEN, P., ed: "The ASME Handbook on Water Technology for Thermal Power Systems", 401 (1989), ASME, New York.

(10) idem: ibid., 403.

(11) Mizuno, T., Wada, K., IwahorI, T.,: Denkikagaku (J. Electrochem. Soc. Jpn.), (in Japanese), 47, 39 (1979).

(12) QUIST, A.S.: J. Phys. Chem., 74, 3396 (1970).

\section{II -2 高温水中の材料のふるまい と水質のモニタリング}

\section{東京理科大学 㰌 孝二}

\section{1.はじめに}

高温水中に括ける金属あるいは金属複合村料の煡全 性を維持するといらことは，とりすなおさず，それら の腐食ならびに劣化をいかに抑制するかといらことに かかっている。

BWRの場合，腐食形態は $\mathrm{Fe}$ 基合金配管の均一策食 とSCCが主要なるのであるが，その抑制は安全性の向

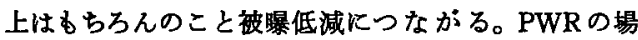
合は, $\mathrm{Ni}$ 基合金の SG の減肉腐食と惢力腐食または粒 界損伤が主たるるのである。いずれにしろ金属側の要 因に対しては，材料の吟味·变更および熱影響部の解 消等の手段が講しられてきており，水質側要因に対し

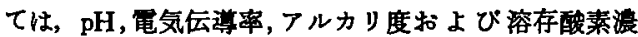
度のコントロール,各種コンタミの除去等の対策が講 ヒられてきた。

本節では，材料の物理的·機械的劣化を除き，简食 の諸要因ならびに高温水に対するいくつかのモ二タリ ンク技術の動向を探ってみることにする。

\section{Fe基合金の府食一BWR環境を中心に}

BWRの 1 次冾却系では，周知の上うに炭素鋼扰よ びステンレス鋼の属食(主にSCC)が中心的問題であ る。腐食は，溶液中に酸素以外比特別な酸化削を含主 ない限り，水の分解(水素発生反忘-溶存酸素浱度が数 $100 \mathrm{ppb}$ 以下の場合)あるいは酸素僄元反応(溶存酸柰 港度が約 $1 \mathrm{ppm}$ 以上)が主要なカンード反応となり，
これに容解反応(フノード反応)がカップルして進行す るとするのが妥当である。これらの反応を加速する因

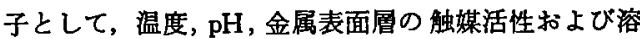
存酸素濃度である。もちろん適当な榢間があれば，䏚 間部で液性が変化して腐食が加速されることは充分考 えられる。液性の変化によって，ネルンスト式*の適 用からもかかるように，隙間部とそうでない部分との 間汇電位差を生じからである。

極性溶媒の解離定数は一般に温度の上昇に伴って增 加するが，水についても同様であって $250{ }^{\circ}$ 付近で最 大になる $\left(\sim 10^{-11}\right)(1)$ (3)。それ以上の温度では減少に転 ずる。純水の $\mathrm{pH}$ は温度とかなりの相関をむつにして す, bulk 溶液の $\mathrm{pH}$ 变化は大きくはなく，反応速度を 加速する温度と，カソート反応の主体である酸素浱度 とが腐食の主要因とみなされる。均一腐食について， 炭素鋼とステンレス鋼の腐食に対する温度と溶存酸素 湿度の影響を見たのが第 I-2(1) 国(3)と第 I-2(2) 园(4)であ る。

炭素鋼の属食は，酸素滣度の大きいときにはその海 度が大きい注と，そして温度の上昇とともに加速され るが，150〜200Сを境抑制される。酸素の還元反応 を考えるとき，腐食が極大となるピーク温度の出現恃 ないはずである。よく知られているよらに，これは酸 化物皮膜の生成によるすのである。温度の上昇に伴っ てアノード反応， $\mathrm{Fe} \longrightarrow \mathrm{Fe}^{2+}+2 e$ 性加速されるが， $\mathrm{Fe}^{2+}$ とカソード反応によって生した $\mathrm{OH}^{-}$とから最終 的にマダネタイト $\left(\mathrm{Fe}_{3} \mathrm{O}_{4}\right)$ 皮膜が表面に生成する。こ

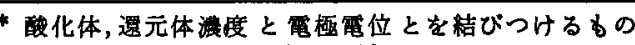

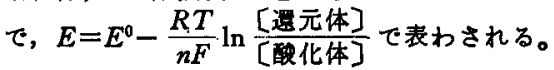
ここで, $E^{0}$ : 標染電極電位, $n$ : 関与する電子数, $F: フ ォ ラ テ ゙ ー ， R:$ 体定数。
} 


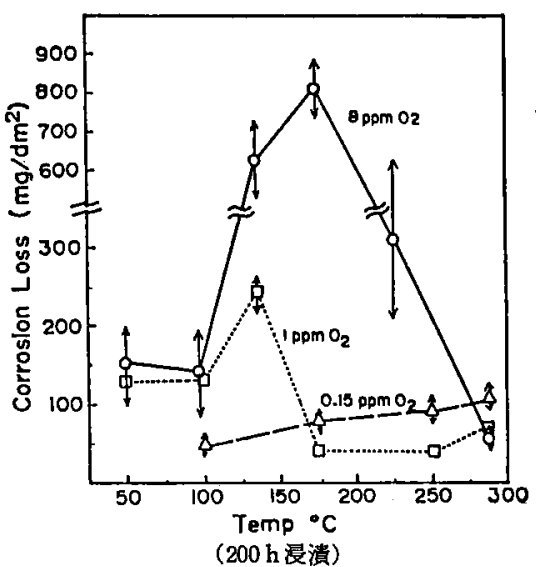

第 I-2(1)図 炭素鋼の腐食に対する 温度と酸素溄度の影翌

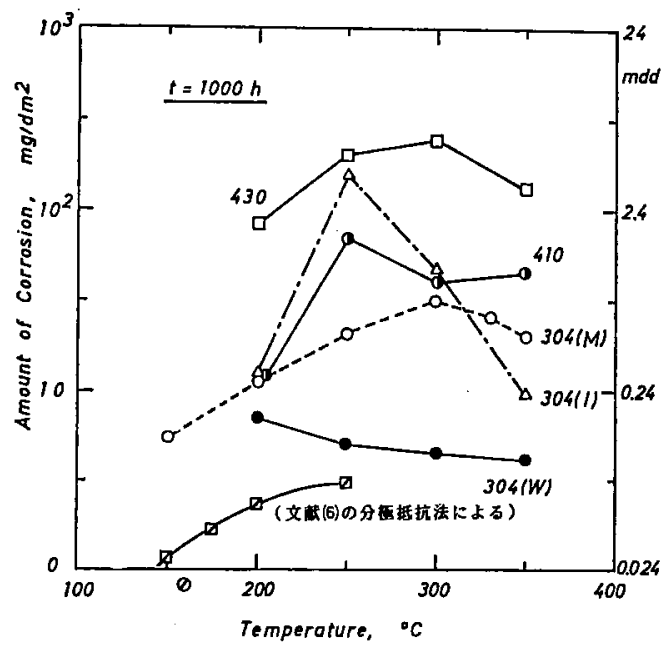

(1, $000 \mathrm{~h}$ 浸清)

第I-2(2)图各種ステンレス鋼の 碝食の温度依存性

のマグネタイト皮膜は，一般に温度の高いはど生成し 易いが，結晶粒も大きくなり下地の溶解を抑制する能 力は小さくなる。酸素浱度の大きいときには，マクネ タイトの表層は溶解度の小さいへマタイト $\left(\mathrm{Fe}_{2} \mathrm{O}_{3}\right.$ る いは $\mathrm{FeOOH)}$ 々酸化され溶解速度は減少する。つま り下地の Feの溶解速度 と表面皮膜の溶解抑制能との 拮抗する温度が，炭素鋼の揚合 $150 \sim 200{ }^{\circ} \mathrm{C}$ といこと の意味であろう。また，表面に生成するマグネタイト は酸素還元に対して触媒作用をる口(5)。定量的な評価 はまたなされていないが，場合によってはマグタイ トのカソード反応促進の効果す考虑してゆく必要があ ろう。
第I-2(2) 図は，ステンレス鋼の腐食量について，酸 素暴度 $100 \mathrm{ppb}$ 以下の純水中に $1,000 \mathrm{~h}$ 浸漬して重量测 定から求めた各機関のデータをとめたるのである。 ステンレス銅においてす，腐食のピークが250〜300゚ に見られる。Crを主とした結晶性のよい表面皮膜が 生成するので，腐食速度は炭素鎆に比べて1/10以下で ある。皮膜は一般に 2 層棈造で, 外層は $\mathrm{NiO} \cdot \mathrm{Fe}_{2} \mathrm{O}_{3}$, 内層はNiO- $(\mathrm{Fe}, \mathrm{Cr})_{2} \mathrm{O}_{3}$ からなり，いずれる結晶構造 はスピネルでする。

第 1-2(3) 図は, $168 \mathrm{~h}, 250^{\circ} \mathrm{C}$ (DO: $0.1 \mathrm{ppm}$ 以下)の 純水に浸漬した 304 鋼の皮膜を真素水で剝離後，IMA (イオンマイクロフナライザー)分析したすのであ る(た。酸素濃度が大きくなれば，表面がへマタイトに 変わることは宸素鋼と同様である。どのような組成の 皮膜が生成するかといらことは，それぞれの温度にお いて作成した電位一pH（T) 図から和特よその推定がで きる。たた酸素港度が大きくなってす，均一腐食速度 は炭素鋼のよ5に極端に増加しない。酸素浱度が大き くなったときの問題はスステンレス銅の電位が高い方 向に移行してSCC感受性が高くなることである。

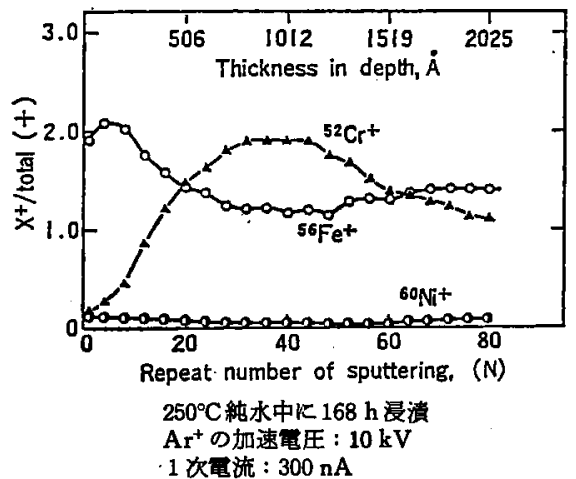

第 I-2(3) 图 SUS 304銅酸化物皮膜の IMA 分析

第 I-2(4) 図は，304ステンレス銅溶接部の SCC 感受 性と電位(SHE 基染) との関俰を示したすのであり(ク， -210〜ー230 mV以下の奄位で粒界SCC(IGSCC)の発 生が抑えられる。奄位をこの基準值以下に抑えるには 酸素漟度のコントロールと水素注入とがあるが，わが 国では前者はすべてのBWRで，後者の方法はATR(第 II-3章)で採用されている(3)。

\section{3. 亩温における水激のモニタリング技赫}

水溶液中の金属材料の席食を論ずる揚合，平衡論と 速度論の両者から考えなければならない。高温水にお いて前者は，まさに水化学(3) といわれるるのである。 


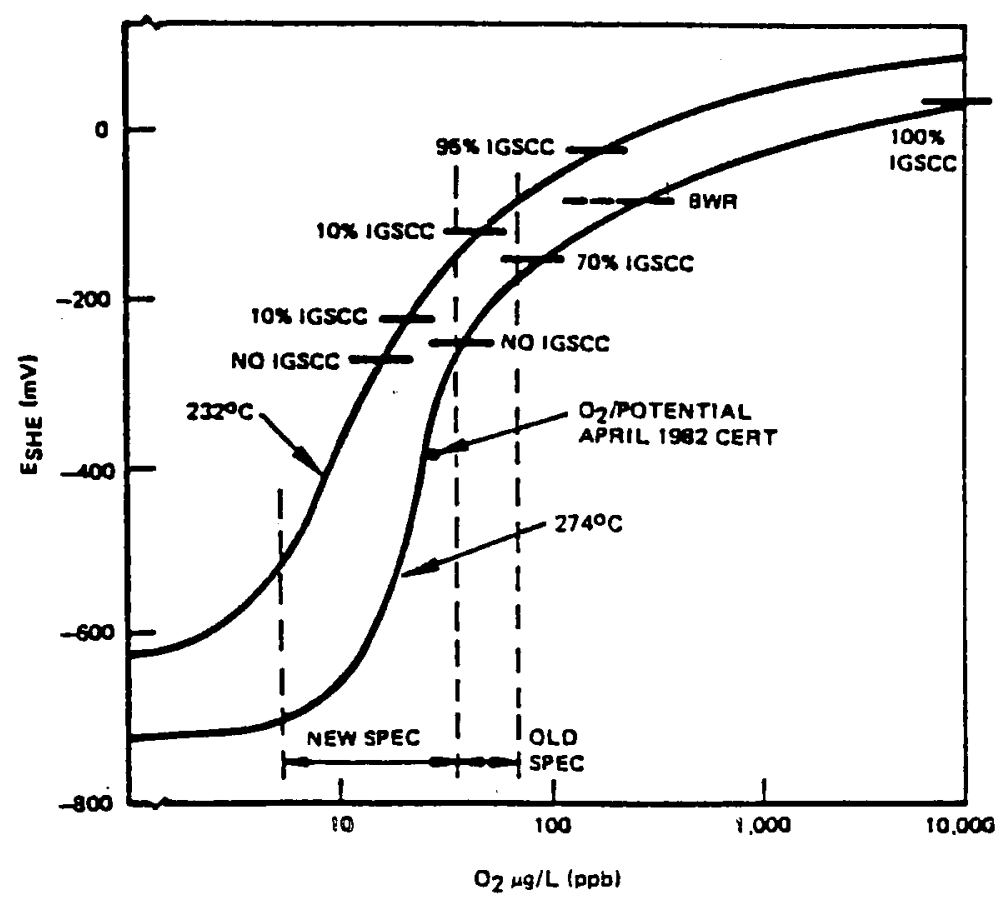

第 I-2(4) 図 304ステンレス鋼溶接部の鷹食電位とIGSCCとの関係

溶存酸素・水素濃度, 電気伝導率, $\mathrm{pH}$, 各化学種の解離 定数,高温水の酸化・還元電位などの湘定が要求され る。

高温水中の酸素濃度を直接高温状態で測定 (in-situ 測定)する試みは，中山ら(8)によってなされてきてい る。PTFE(テフロン)の酸素透過膜を用いたポーラロ グラフ型(電位規制で注目するイオン種の拡散電流を 求める方法)であり，室温から285゚ Cで，出力䉓流と 酸素泿度との間によい直線関係のあることを見出して いる。溶存水素についてはPd線(9)およびPd透過膜のを 用いたセンサーが発表されているが，信頼性はまだ低 い。上記の酸素濃度計を高温水中で長期に使用するに は，酸素透過膜のPTFEからセラミックス系への変更 が必要ではなからうか。例党ば, CVD(化学気相合成) 法やスパッタリング法により透過膜を作ることであ る。

電気层導率を除く他の項目の剆定には，高压下で安 定に作動する照合電極が必要である。この照合電極に あ党て高温という条件をつけないのは，压力をバラン スさせて，高温外人セットすればよいからである。こ の圧力平衡型外部照合電極はすでに開発され(11)，安 定に龟位測定のできることが示されている。高温水中 の金属材料の腐食龟位のモニタリングは, 寸でに述べ
たSCCの感受性評価あるいは皮膜組成の推定といら点 で極めて重要である。ある種のイオンを含む高温水の 酸化·還元電位も，Pt電極を用いて照合電極からの電 位として測定できる。

高温高压办の $\mathrm{pH}$ センサについては, Pt, Pd 水素電 極,半導体電極,ガラス電極などいくつか取り上げられ てきたが,高温水中の酸化・還元系に影警を受けないこ と，高温水中で安定であること，操作が容易なことな どを考慮して，酸素伝導性のイットリア安定化ジル ニフ（以下，YSZ)を用いたシステムが開発されてき た(12)。YSZとしては高温水中で安定な8.5 を含む全安定化磁器が主である。センサーチューブ の形状怙よび内面の $\mathrm{Pt}$ メキ(厚さ $0.5 \mu \mathrm{m}$ ) 状態を 第 I-2(5) 图に示す。チューブ内にはオートクレーブ (高圧容器)の圧力とバランスするようにされた圧縮空 気が通され，内面にメッキしたPtの触媒作用により酸 素電極仕様 $\left(\mathrm{O}_{2}+4 e \rightleftharpoons 2 \mathrm{O}^{2-}\right)$ にされているのが特徵 である。つまりチューブ内外の压力をバランスさせる ことにより，セラミックスの強度を補うというものて ある。第 I-2(6) 図にオートクレーブへの取付けを, 第 II-2(7) 図に圧力平衡器の断面図を示す。平衡器内の ピストン 5 が上下動することで圧力が調整される。 


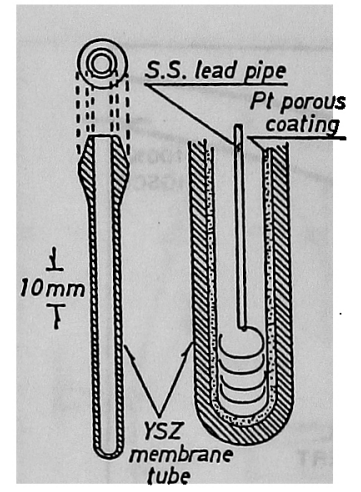

第 I-2(5)図整作したYSZの隔膜

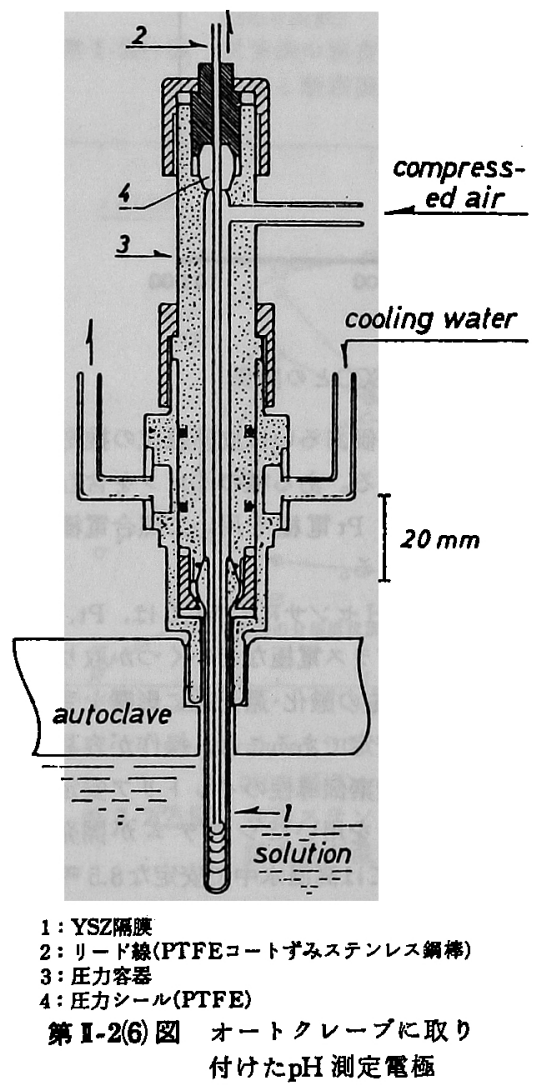

第 I-2(8)图が $\mathrm{pH}$ 湘定の原理であり，ネルンスト式に より $\mathrm{pH}$ が求められる。第 I-2(9) 圂が各種の溶液中で の $\mathrm{pH}$ センサの奄位と, 同時にセットされたPtの西位 とをブロットしたすのである。両者は1：1K対応して おり充分な $\mathrm{pH}$ 応答を示すことがわかる。第 I-2/10 园 は，センサの龟位と計算で求めた $\mathrm{pH}(T)$ とをブロッ トしたすので, この傾きが各温度でネルンスト俰数

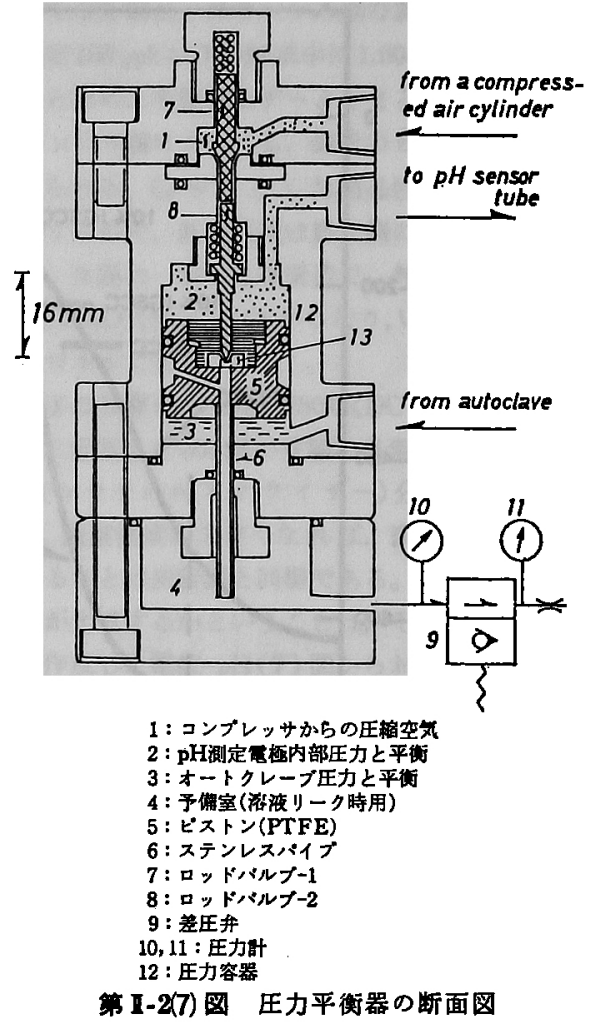

$(R T / n F) \times 2.303$ K合致すればよい。夷際に, $150^{\circ} \mathrm{C}$ か ら2750 まで，25゚ 刻みの測定を行い比较したところ 䄪 $6 \%$ 誤差範囲内であった。このセンサーの $\mathrm{pH}$ 応 答の下限温度は150`Cである。なお YSZの破損は，一 定温度での連続使用より，昇温・降温時に発生し易い と考えられるが，275゚ てで25サイクルの昇温・降温に む(通算約 $450 \mathrm{~h}$ ) 破損していない。

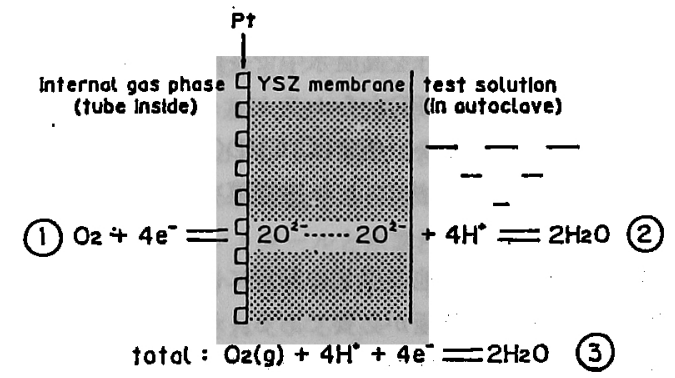

第 I-2(8)图 YSZ電極によるpH測定の原理

4.おわりに

BWRの高温水㻴境に限って金属材料の府食に若于 


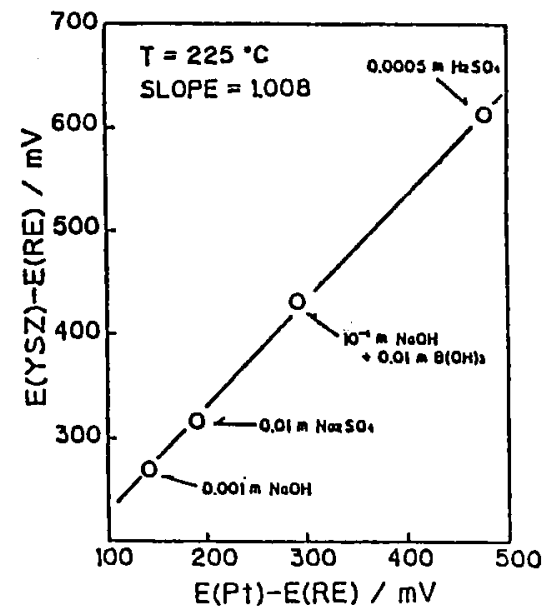

8. $5^{\mathrm{mol}} / 6 \mathrm{Y}_{2} \mathrm{O}_{3}$ 添加 $\mathrm{YSZ}$ 管

第 I-2(9) 図種々の溶液についての pH電極 とPt電極の電位測定結果

触れた。当然のことながら，腐食は環境の水質と材料

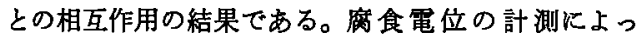
て，SCC 感受性をかなり予知できるようになってきて $お り$ ，さらKDO(溶存酸素)， DH(溶存水素)， $\mathrm{pH}$ 等の in-situモニタリンダ法の開発によって, 精度のよいさ め細かな水質コントロールと高温水の各種データの取 込みのなされることを期待したい。

\section{一考文献一}

（1）岡部秦二郎,他 : 電気化学, 39, 258, 340 (1971).

(2) 向坊 隆, 增川重彦: 同 上, 32, 252, 336 (1964).

（3）水野孝之：同 上，59，282（1991）.

（4）开藤伍郎：銅，第63年，345（1977）;

檑 孝二：第32回腐食防食討論会粨演集，札幌 (1985).

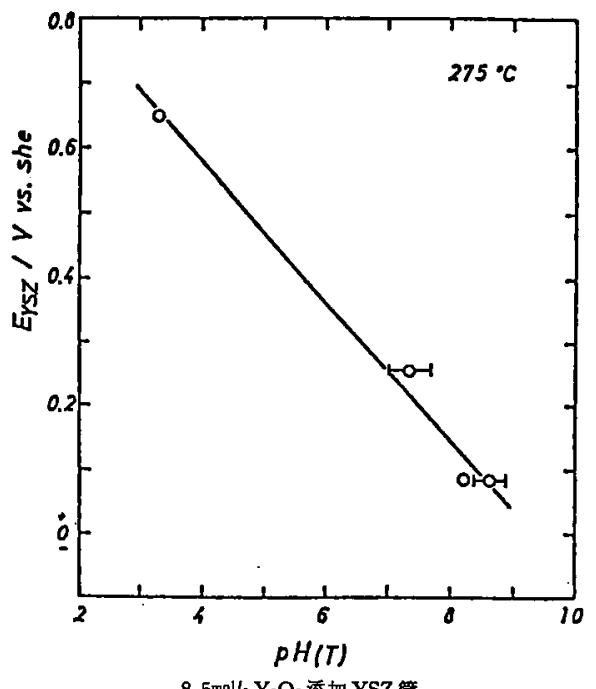

$8.5^{\mathrm{mol}} / \% \mathrm{Y}_{2} \mathrm{O}_{3}$ 添加 $\mathrm{YSZ}$ 管

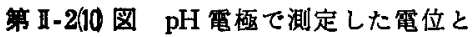
計算で求めた $\mathrm{pH}$ との比較

(5) Fujit, K., Tachibana, K., YoKor, M.: Corrosion Eng., 37, 295 (1988)

(6) Tachibana, K., Fujita, N., OsaKa, T.：防食技 術, 29, 491 (1980).

(7) INDIG, M.E., et al.: "Water Chemistry of Nuclear Reactor Systems-2", ㅁ15 (1986).

(8) Nakayama, N., Ozawa, Y., Uchida, S.: J. Nucl. Sci. Technol., 19[8], 678 (1982); 21[4], 288 (1984); 21[6], 476 (1984).

(9) Macdonald, D.D., et al.: Ind. Eng. Chem. Fundam., 20, 290 (1981).

(10) 小沢義弘, 内田俊介, 中山紀夫：特開 昭58-215549.

(11) Tachibana, K., et al.: Proc. 4 th APCCC., p 1275 (1985).

(12) 㛢 泺二, 他：材料と環境，40，308（1991）。

\section{III. 実機プラントの水化学管理技術}

\section{III-1 BWR の場 合}

東京電力椎 天 野 治

\section{1. 概 要}

水化学管理の目的は，機器の健全性を維持すること のほかに，放射性線源の蓄積を抑制すること，水を浄 化する眖塩装置等を極力有効飞活用し，そこから発生 する使用珮及樹脂等の放射性廃棄物の発生量を低隇す ることである。

これらを達成するための体系だったデータの採取・
評価を行らプログラムが，1970年代から電力,プラン トメーカーと一体となって始まり，機器および燃料の 健全性維持, 線量低減, 廃棄物発生低隇が着実に成果を 上げ，現在む進行しているところである。特に最新ブ ラントでは，線量低減，廃棄物低減等であ界でもトッ プレベルの実績を持つまでに至っている。

\section{2. 水化学管理の体系}

BWR は，冷却水である軽水が沸騰し，燃料情表面 で不純物の濃樎が起こることが特徽である。

これまでは，金属試験片の高温水中での試験結果等 
から, 原子炉水中の不純物濃度の許容上限值を定め, その値を超えない上ら原子妒水，給復水等の上流側の 水質を管理してきた。そのため各系統ごとに，オンラ インで不純物のグロス量を $\mathrm{pH}$ 計や導電率計で連続的 に監視するほか，定期的にオフラインで金属，シリカ， イオン種等の不純物涱度をイオンクロマトクラフィや 䖝光 X線分析装置等で測定し, 数多くの測定データに ついて評価を行なっている。

水化学管理は，これらのデータをると，確実にか つ最新の知見や技術を效率的に取り入れるために, 基 本的には以下の体系で実施されている。

（1）試料採取点の選定 (原子师水，給復水，各種净 化系出入口等), 分析項目, 分析頻度の㭘討

(2) 分析機器の点検, 分析精度の向上

(3) 得られたデータの評価・対策の実施(浄化系脱 塩䒾置㯕脂の交換等)
（4）本店·発奄所・電力およびブラントィーカー間 での実務者レベルでの情報交換

(5) 本店・発電所・電力およびブラントメーカー間 での管理者レベルでの情報交換

(4)においては、これまでの検討結果を電カ・ブラン トメーカーがそれぞれ発表・協議して知見を深めると とすに，対策を施す一助としている。さらに(5)におい ては，実務者ばかりではなくブラント全体を見渡す管 理者も参加し幅広く活動しているのが特徽である。

\section{3. 最近の水化学管理の成果}

これまでの水化学管理により，線量低減，然料等の 機器の一層の健全性の向上, 哭衰物の発生量の低減が 园られつつある。その一部を以下に紹介する(第 I-1(1) 国参照)。

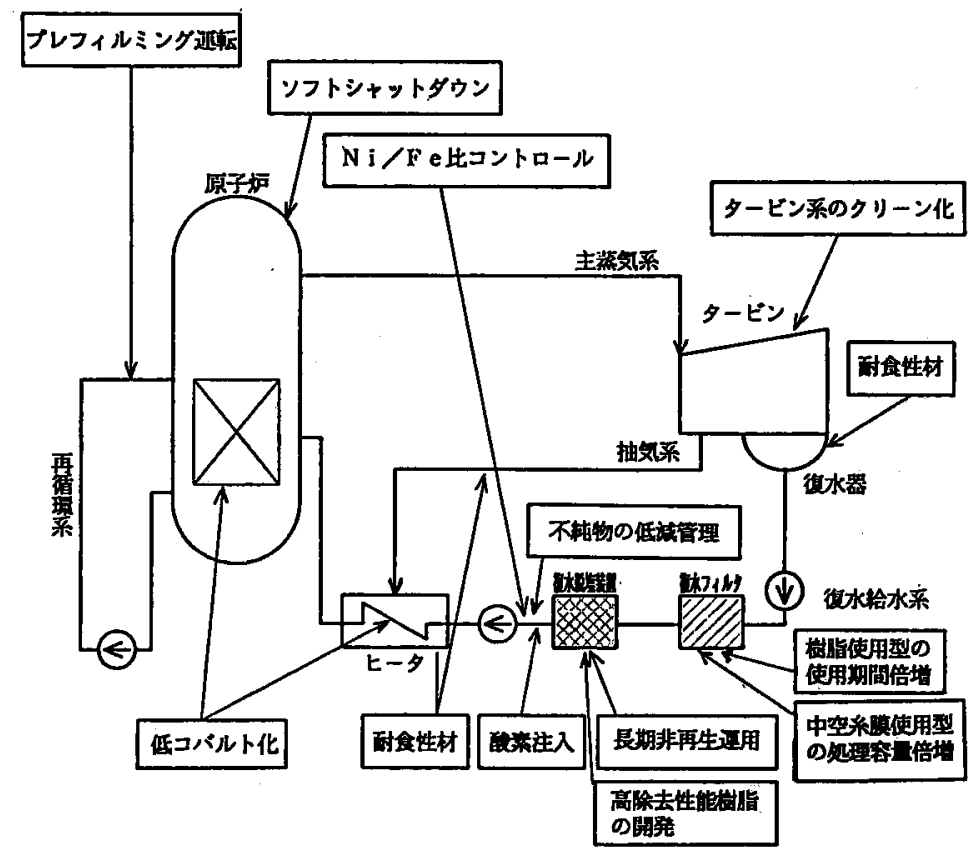

第 I-1(1) 図 BWRブラントの系統粠成と水化学管理技術

(1) Ni/Fe比コントロール等による

\section{機器への放射能付着低娍}

冷却水に接しているステンレス銅製等の機器からは CoやNiかi溶出し, 然料からの放射線に上る放射化後, 機器に付着することにより,ブラントの盼团気線量率 が上がる。このため，Cの含有量の少ない素材（低Co 材）を選定するととる，使用する前脿面に安定·強
固な酸化被膜を施す運用(プレフィルミング運転)等に より不純物の被膜への取込みを抑制するほか, 給復水 系に復水フィルタを設膡することにより原子炉へ持ら

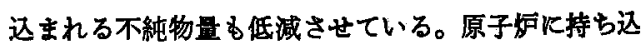
まれたごく微量の不純物については，然料捧表面で安 定化させるため，その不純物渡度(特にNi)に合わせて $\mathrm{Fe}$ 濼度を調整し， Feとの安定酸化物を形成させる(Ni/ 
$\mathrm{Fe}$ 比コントロール)。

現在適用プラントは福島第二原子力発奄所 2 号機 (2F-2)以降の 9 プラントに達し，世界的に倛れた線 量低減を達成している。2F-2 以前のブラントについ てる，途中からではあるが， $\mathrm{Ni} / \mathrm{Fe}$ 比コントロールの 概念でFe 港度を管理している。

一方，原子炉停止時においては然料に安定に付着し
た放射性不純物を剩離させないように，冷却速度を抑 えた停止方法(ソフトシャットダウン)を採用してい る。

これらの対策により，配管表面線量率および雰国気 線量率が低減してきており，線量当量す年々減少して いる(第 I-1(2) 図参照)。

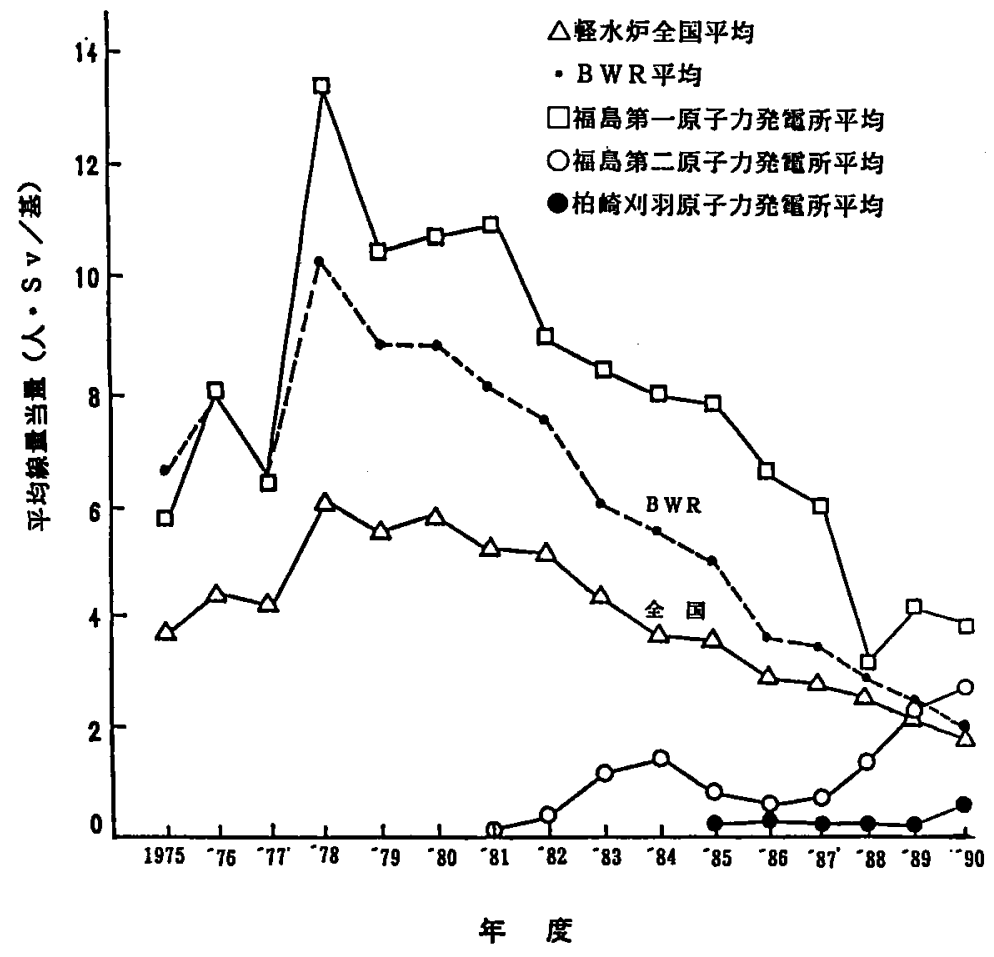

第 I-1(2) 图 国内原子カブラントの平均楾量当量の推移

（2）原子沪水底液はすへて度菓物処理系

移送によるターピン系のクリーン化

線源の拡散防止の観点から，定検中の原子妒ウェル 水, 運転中のサンプリング水が直接タービン系復水器 に流入しないよらにこれらの㾔液をすへて廃棄物処 理系移送に変更した。この結果,タービン系の㞣囲気 線量率は大幅に低減し，クリーン化が図られている。

(3) 紎料の一原の健全性向上のため

\section{不䢁物瓶度の監視}

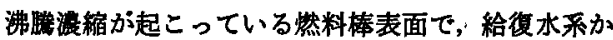
ら持ち込まれる不純物は，その持込み量が多くなると 展食を增加させる可能性があり，濐度の監視と不純物 の低減対策を講じている。
（4）緎維状澍脂採用による得水フィルタ (樹脂使用型)の樹脂使用期间の倍增

水と苲気が混じる復水器等では主に鉄錆が発生し, 原子炬に持ら込まれると放射化する。このため，福島 第二原子力発電所 1 号機 (2F-1) 以降のブラントでは, これらの部分に锖びにくい材料(耐食材)を選定すると ともに，復水脱塩装監の前に粉末状の樹脂を使用した 復水フィルタが設置され，鉄錆の持込み量の低减を図 っている。しかしながら，使用済み樹脂の放射性廃㲤 物の発生低減の観点から，鉄錆の沪過過程での差圧上 算のメカニズムを解明し，差圧上昇抑制に効果的な維 維状樹脂の採用と最適な運用方法の確立により，使用 期間を従来の 2 倍以上に延長し，廃棄物低減を図って いる。 
（5）復水脱塩装置澍脂の非再生正用

復水脱塩装直樹脂は従来, 年 2 回程度薬品により不 純物除去機能の蘇生を図っていた。しかしながら，使 用済みの薬品廃液が放射性廃棄物になることから、こ の発生低減に取り組んできた。特に, $2 \mathrm{~F}-1$ 以降のプ ラントでは復水フィルタの設㯰により, 復水脱塩装置 への鉄錆等固形状不純物の負荷が減少したことに着目 し，樹脂そのむのを測定することによりイオン状不純 物の負荷の把握と運用面からの負荷軽減策を実施し, 䄪 7 年間の非再生運用を達成し, 大幅な廃裹物低減が 函れた。

\section{（6）復水脱壏装昷の高除去性能樹脂の開甡}

2 F-1以前のプラントでは, 給復水系に100\%系統処 理容量の脱塩装置と, 起動時の給復水系の浄化のため の復水フィルタ(中空糸膜使用)とが追加設置されてい る。この装置は, 起動時を主眼に約30\%容量で設計し てある。しかしながら, 起動時以外の通常運転中す原 子炉に持ら込さ鉄錆量を低減する必要珄があり，この 復水フィルタを通常運転中も使用する(約30\%容量)と 共に, 復水脱塩装固樹脂の影微鏡観察や樹脂含水率之 の相関から鉄錆除去メカニズムについて検討した。除 去性能を大幅に向上した樹脂を開発し, 福島第一原子 力発電所 6 号機 $(1 F-6)$ において現在試験中である。

\section{（7）復水フィルタ(中空系膜使用)の}

\section{処理容至の倍增}

復水脱塩装置ではイオン状不純物の除去を行い, 鉄 錆等のクラッド状不純物は復水フィルタ（中空系膜使 用)で捕捉除去する方が放射性廃棄物発生低減の観点 からは効率が良い。このため(6)と並行して 2 F-1 以前 のプラントに追加設直された約 $30 \%$ 容量の復水フィル 夕(中空系膜使用) の通水流速を增加させ, $100 \%$ 容量 に近付けるよらに検討している。この方法として中空 糸膜の材質や制造方法を改善することで，従来の約 2
倍の処理が可能であることが，ミこモジュール試験で 確認されている。今後, 実機適用に向けて検討中であ る。

\section{4. 今後の水化学管理の取組み}

（1）水環境の直接連続モニタリング

前述の水化学管理の成果を標準化し，すべてのブラ ントに長期にわたり適用することが重要である。この ためにも，今後は原子炉水や給復水の水愣境をグロス だけではなく、イオン種を直接・連続的にモ二タリン グする技術が望まれ，オンラインのイオンクロマトク ラフィ, TOC(全有機炭素)メータ等が一部荚用に供さ れ始めている。さらにステンレス鍴側から見ての腐食 裳境の長期的な測定も重要であり, 今後の検討課題で ある。

一方，BWRの特徵である燃料棒表面での沸滕濃綰 举動は, 高温であること等の制約から直接的なモ二タ リングはなされず，線量低隇対策など，その時々の興 味ある事象に対しての追試的な調査に追われていた。 今後は体系的な調查およびモ二タリング技術の開発が 望まれる。

（2）調查·検討·停価ブログラム

これまでは初期事象に対して，あるいは短期事象に 対してモニタリングを実施し，対策を講じてそれなり の成果を上げてきた。今後の課題としては，長期的な 事象および予期されない事象に対し，早めに徵候を検 知することはるちろん, 事象発生の可能性を国, 大学, メーカーの広範な研究分野等の協力を得て予知 L, 予 防保全的に管理を実施すべきであることが，福井県で 行われた「1991水化学国際会議」で提唱された。

これらを具体的かつ効果的に実施する調查・検討・評 価プログラムについて，今後積極的に議論を進めるこ とが望まれる。

\section{III-2 PWRの場合}

関西電力西 村 健

わが国に括ける運転中の PWR プラントは19基を数 えており，初号機の美浜発電所 1 号機の運転開始以来， 21年が経過している。この間, ブラントの安定運転の ために水化学管理の果たしてきた役割は小さくない。 PWR ブラントは, SGを介して1次系と 2 次系に分 かれているので，両系統独立に，それぞれの系統に適
応した水化学管理を行なっている。

\section{1 次系の水化学管理}

\section{（1） 1 次系の水化学管理の考え万}

1 次系の水化学管理の目的は, 妒心反度度制御, 系 統構成材料の腐食㧕制扰よび被㫜低減である。このよ らな観点から，第 $\mathbf{I}-2(1)$ 表の 1 次冷却系統の水質仕棣 に示すよらに, 1 次系には㛒心反応度制御に用いるホ ウ酸のほかに，水質をてルカリ側に維持するため水酸 化リチウムを，水の放射線分解による酸素発生を制御 
第正-2(1)表 1 次冷却系統の水質仕棣(例)

\begin{tabular}{|c|c|c|c|c|}
\hline \multicolumn{2}{|c|}{ 分析項目 } & 基準值 & 制限值 & 実績値 \\
\hline $\mathrm{pH}$ & (at $25^{\circ} \mathrm{C}$ ) & $4.2 \sim 10.5^{\dagger}$ & & \\
\hline 遵電率 & $\left(\mu \mathrm{S} / \mathrm{cm}\right.$ at $\left.25^{\circ} \mathrm{C}\right)$ & $1 \sim \mathbf{4 0}$ & & \\
\hline B & (ppm) & $0 \sim 4,000^{\dagger \dagger}$ & & \\
\hline 塩化物イオ & (ppm) & $\leqq 0.05$ & $\leqq 0.15$ & $<0.05$ \\
\hline 溶存酸素 & (ppm) & $\leqq 0.005$ & $\leqq 0.1$ & $<0.005$ \\
\hline 溶存水素 & $\left(\mathrm{cc}-\mathrm{STP} / \mathrm{kg} \cdot \mathrm{H}_{2} \mathrm{O}\right)$ & $25 \sim 35$ & $\geqq 15 \leqq 50$ & $\sim 30$ \\
\hline $\mathbf{L i}$ & $(\mathrm{ppm})$ & $0.2 \sim 2.2$ & & \\
\hline
\end{tabular}

するため水素ガスを添加している。

これまで 1 次系の水質は安定して括り，水質に起因 するトラブルす発生していないことから，水質仕梯は 当初と全く変わっていない。このような訳で，1次系 の水化学管理の主要な目的は被懪低減となっている。

\section{（2）被曝低減技街}

PWRブラントにおける主な被曝線源は ${ }^{58} \mathrm{Co}{ }^{60} \mathrm{Co}$ あり，その親元素である $\mathrm{Ni}$ を主体としたCPの発生源 は，主としてSG等のほ心外の機器・配管である。した がって，被曝低減を図るには次の対策が重要となる。

(1)腐食抑制：金属材料から腐食生成物(CP) とし て放出される NiとCoの量を少なくす る。

(2)放射化抑制：CPが炉心領域，特に然料表面に沈 着するのを㧕党る。

(3)污染防止： 定期検査する機器配管表面に ${ }^{58} \mathrm{Co}$, ${ }^{60} \mathrm{Co}$ が沈着するのを抑える。

(4)放射化された CP(クラッド)の除去：クラッド を溶解・剥離させて，浄化設備によっ て除去する。

これらの目的を達成するため，プラントの運転状熊 に応して次のような水質管理を行なっている。

\section{（1）㯰転中の管理技術}

放射性CPの発生抑制には $\mathrm{pH}$ 管理が重要であり，プ

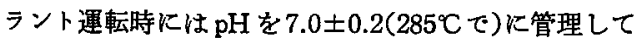
いる。その結果, 冷却材中のCP濃度は低く維持されて いる。例えば， ${ }^{58} \mathrm{Co}$ の湴度はプラント間で多少差はあ るが $1 \mathrm{~Bq} / \mathrm{m} l$ 程度である。なお，さらに $\mathrm{pH}$ 管理の最 適化を進めるため，現在国内外で調査研究が実施され ており，各発龟所ではその成果を活用する方向で $\mathrm{pH}$ 管理の改良を図っている。

\section{（2）炉停止操作時の管理技術}

ブラント停止時の水質管理はCP除去を主目的にし ている。そのためには，水質をCPの溶解を促進する 条件に管理する必要があり，具体的には，早期のホウ
酸添加と， $\mathrm{Li}$ 除去による低 $\mathrm{pH}$ 管理と，600 よりやや 高めの冷却材温度管理を行なっている。な㧊最近は, 冷却材中のクラッド成分のらち, 金属 $\mathrm{Ni}$ 溶解が溶存 水素濃度が低いと促進されることに着目し，低溶存水 素の濃度管理によるCP溶解促進法が実用化されつつ ある。

\section{（3）温態機能試験(HFT)時の管理技術}

プラントの線量当量率の経年変化を見ると, 運転開 始後 $1 \sim 2$ 年で急增し, その後增加傾向は極めて緩や かになる。これは金属材料の腐食举動と類似してお りプラント初期段階で耐食性に優孔た酸化皮膜を形 成させることが，被曝低減化につながることを示唆し ている。

このよらな観点から，試運転段階のヒートアップ前 に出力運転時の温度に近い高温で実施される HFT 時 に保讙被膜形成を目的とする水化学管理が行われてい る。最近では，HFT時の水質を溶存水素 $30 \mathrm{cc} / \mathrm{kg}, \mathrm{Li}$ $0.5 \mathrm{ppm}$ 管理する「 $\mathrm{H}_{2}$ ガス $+\mathrm{Li}$ 添加法」が泊 1 号機以 降のブラントに適用され，効果を上げている。

被曝線源強度は，第 $\mathrm{II}-2(1)$ 図の SG 水室内線量当量 率の例からかかるよらに減少傾向を示して特り，最近 のプラントでは定期検查時の線量当量がかなり低下し ている。こ机には定検作業の自動化や噫蔽の強化のほ かに,このよらな水化学管理が貢献しているものと思 われる。

\section{2 次系の水化学管理}

（1） 2 次系の水化学管理の考え方

2 次系の水化学管理の目的は, SGの伝熱管損傷の 防止およびタービンを含む 2 次系機器の健全性の稚持 にある。SGの 2 次側の伝熱管腐食の原因は，伝熱管 と管支持板の隙間(クレビス部)に濃縮した水中溶解不 純物之考えられて括り，不純物の種類により減肉,粒 界腐食/SCC 等の腐食が生じる。

したがって，これらを防止するためには次の3点が 


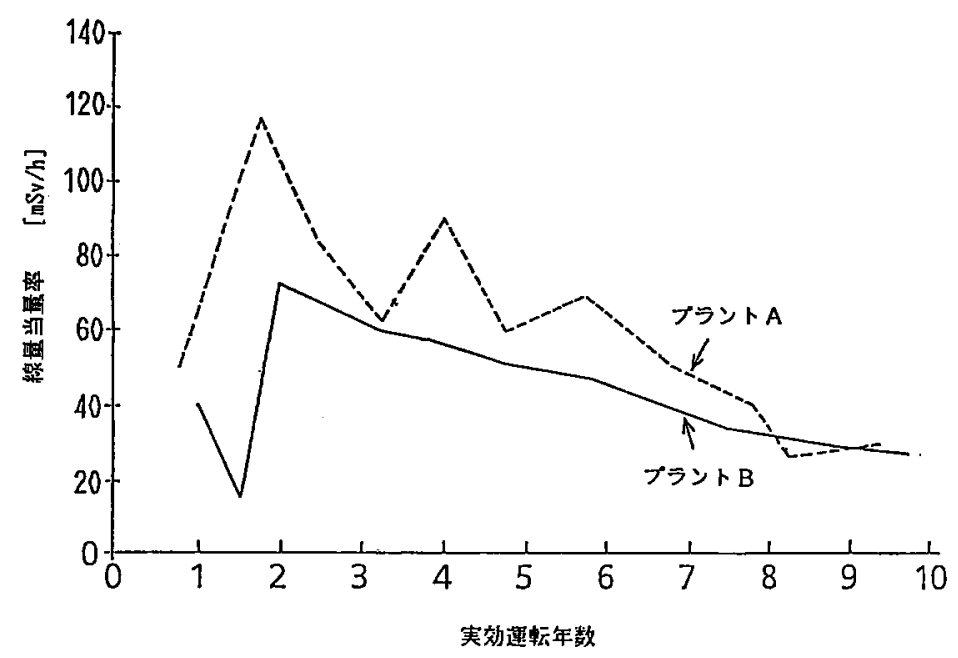

第 I-2(1) 図 SG水寊内の線量当量率の経年变化(例)

2 次系の水化学管理の基本となる。

(1) 系統内への不純物の持込み防止

（2）持ら込まれた不純物およびCPの除去

(3) 系統搆成機器の窝食抑制

基本の第 1 は，系統内への不純物の持込み防止であ り，具体的には，冷却海水お上び空気の漏洩に対し復 水器の信頼性向上を図るととるに, 補給水処理装直の 適切な管理非よび水処理薬品(フンモニアととドラシ ン)中の不純物管理がある。

第 2 には，持ら込まれた不純物およびCPの除去であ り，復水脱塩装置の設置とその適正運用，クリーンア ップシステム执よびSGブローダウン回収システムの 設值とその有効利用, そして脱気器による溶存酸素の 除去が挙げられる。

第3 として，薬品添加(フンモニアおよびヒドラジ ン)による系統構成機器の有食抑制が挙げられる。

(2) 2 次系の水化学管理のための設供

このような考え方を達成するため，2 次系では以下 のような設備の充実と信頼性の向上が図られている。

(1) リークタイト復水器

不純物持込みの最大の要因は, 復水器からの海水漏 洩である。そのため, 復水器冷却管では定期検査時に 全数を対象に各種検查が行われており，不具合個所の 改善,施栓等を行らことにより, 復水器の信頼珄の維 持に努めている。また最近では，さらに信頼性の高い Ti管が採用されて拉り，海水漏洩に対する信頼性はよ り向上している。

（2）復水脱塩装直

系統内に持ら込まれた不純物を除去するため，最す
有効な方法は復水脱塩装㕆の設直である。復水脱塩装 置は復水器の海水漏洩を想定し，SGへの混入を防止 するために設置されているものであるが，てれ以外に わ，起動時の系統浄化，通常時の水質向上に効果的て あり，現在，日本のすぺてのPWR プラントに適用さ れている。

復水脱塩装置の運用にあたっては，樹脂再生時の再 生剂による逆再生防止が重要となるが. 近年, カチオ ン樹脂とアニオン樹脂の混合層を抜き出して，再生剂 が触れないようにできる 2 塔再生方式が採用されてい る。

\section{（3）2次采の水質監視計器}

2 次系には水化学管理が商切に行われていることを 監視するために，第 I-2(2) 図に示すように，系梳の各 所に水質監視計器が設置されている。これらの水質監 視計器には，酸素が持ち込まれていないことを確認す る溶存酸素計,不純物が持ら込まれていないことを確 認する酸導電率計, $\mathrm{Na}$ 計のほか, 系統構成材が腐食し にくい環境にあることを確認する $\mathrm{pH}$ 計などがある。 これらのらち, SG 层熱管の損伤防止の観点から,近年 重要な役割を果たしているのがSG 器内水の不純物浱 度を連椯監視する連続監視型イオンクロマトグラフィ 一である。この装置は，(1)項で述べたような水質管理 の徹底により低濃度に管理されている不純物を正確に 剆定するために導入された装膡であり，手分析時の㬿 量成分の混入を防止し，煩雑な操作から分析員を開放 するのに有効な機器であるので，各ブラントに採用さ れている。第 I-2(2)，-2(3) 表に，この装㯰の测定イオ ン種，测定範囲おょび測定例を示す。 


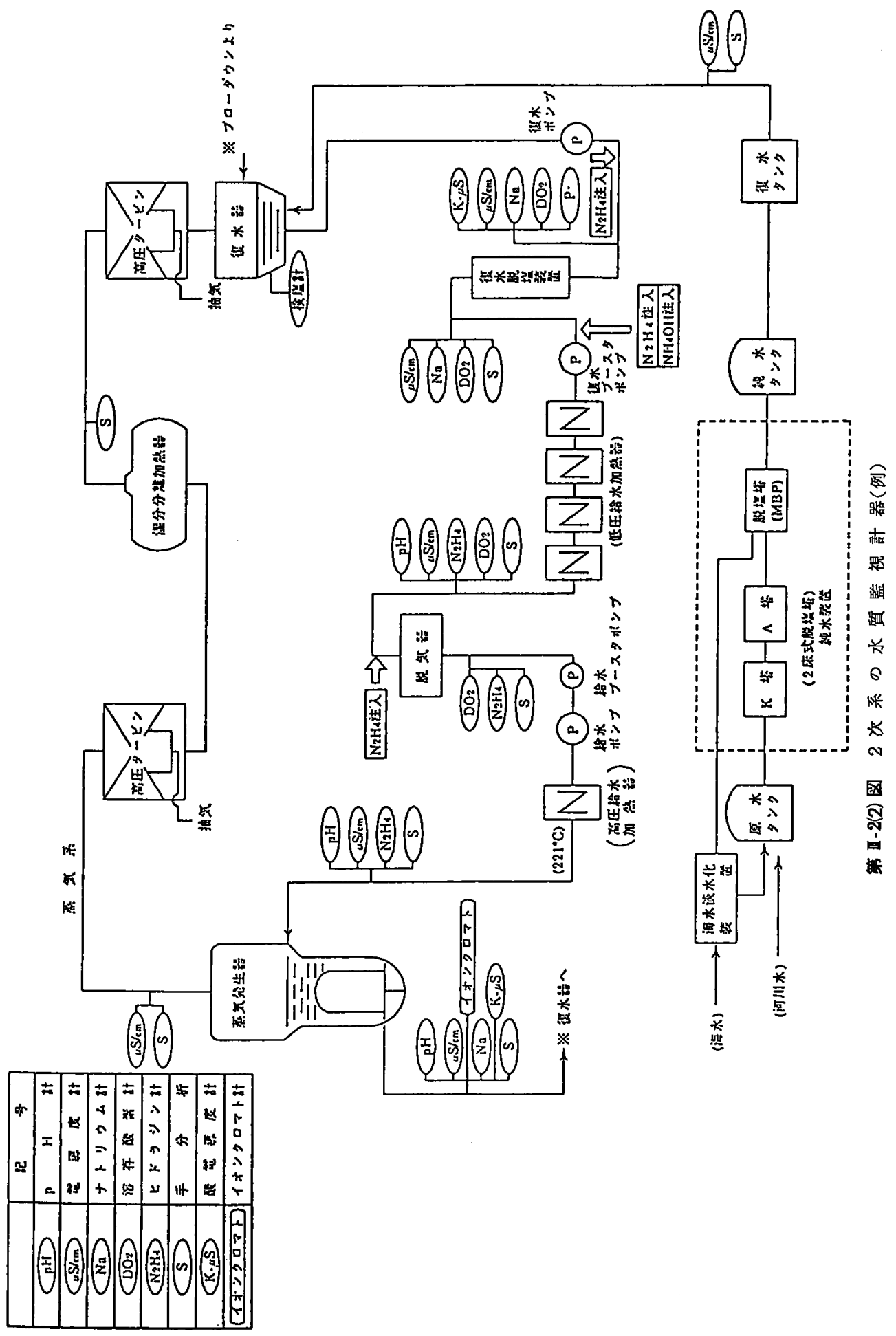


第 I-2(2) 表 測定イオンおよび測定範围

\begin{tabular}{ccrc}
\hline イオン種 & & $\begin{array}{c}\text { 測定範囲 } \\
(\mathrm{ppb})\end{array}$ & $\begin{array}{c}\text { 測定周期 } \\
\text { (min) }\end{array}$ \\
\hline 陰イオン & $\mathrm{Cl}^{-}$ & $0.1 \sim 1,000$ & 30 \\
& $\mathrm{SO}_{4}{ }^{2-}$ & $0.2 \sim 1,000$ & \\
1 価陽イオン & $\mathrm{Na}^{+}$ & $0.1 \sim 1,000$ & 30 \\
& $\mathrm{NH}_{4}^{+}$ & $10 \sim 2,000$ & \\
2 価陽イオン & $\mathrm{Mg}^{2+}$ & $0.1 \sim 1,000$ & 30 \\
& $\mathrm{Ca}^{2+}$ & $0.2 \sim 1,000$ & \\
\hline
\end{tabular}

第 I-2(4) 表 代表的な SG 器 内水の水質

\begin{tabular}{lccc}
\hline \multicolumn{1}{c}{ プラント } & $\mathrm{A}$ & $\mathrm{B}$ & $\mathrm{C}$ \\
\hline 酸導電率 $(\mu \mathrm{S} / \mathrm{cm})$ & 0.3 & 0.1 & 0.2 \\
$\mathrm{Na}(\mathrm{ppb})$ & 0.1 & 0.2 & 0.3 \\
$\mathrm{Cl}(\mathrm{ppb})$ & 0.3 & 1.1 & 0.3 \\
\hline
\end{tabular}

第 I-2(3) 表 通常運転時の SG 器内水の 水分析結果(例) (単位: $\mathrm{ppb)}$

\begin{tabular}{|c|c|c|c|c|c|c|}
\hline 時間 & $\mathrm{Cl}^{-}$ & $\mathrm{SO}_{4}{ }^{2-}$ & $\mathrm{Na}^{+}$ & $\mathrm{NH}_{4}^{+}$ & $\mathrm{Mg}^{2+}$ & $\mathrm{Ca}^{2+}$ \\
\hline $01: 08$ & 0.56 & 0.52 & 0.31 & 165.00 & 0.09 & 0.21 \\
\hline $02: 38$ & 0.77 & 0.50 & 0.24 & 165.00 & 0.09 & 0.26 \\
\hline $04: 07$ & 1.32 & 0.50 & 0.23 & 165.00 & 0.11 & 0.21 \\
\hline $05: 37$ & 1.18 & 0.46 & 0.24 & 166.00 & 0.10 & 0.23 \\
\hline $07: 07$ & 1.04 & 0.46 & 0.20 & 167.00 & 0.10 & 0.21 \\
\hline $08: 37$ & 0.92 & 0.46 & 0.20 & 169.00 & 0.10 & 0.24 \\
\hline $10: 07$ & 0.83 & 0.45 & 0.20 & 168.00 & 0.10 & 0.28 \\
\hline $11: 37$ & 0.82 & 0.53 & 0.20 & 164.00 & 0.09 & 0.18 \\
\hline $13: 07$ & 0.77 & 0.52 & 0.26 & 166.00 & 0.10 & 0.26 \\
\hline $14: 37$ & 0.76 & 0.52 & 0.17 & 165.00 & 0.09 & 0.22 \\
\hline
\end{tabular}
維持されている。

により直接タービンを回転させており，炉心構造を除

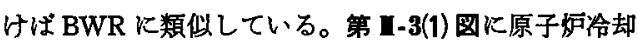
系を中心とした系統の概略を示す。原子炉冷却系は独 立 2 ループで，然料を収めた圧力管は各ループ112本 である。冷却材は再循環ポンプで下部へッダに送ら れ，ここで個々の入口管に分かれ，圧力管内を上昇し つつ沸腃し，蒸気と水の二相流となり上昇管を通って 蒸気ドラムに入る。蒸気ドラムで蒸気と飽和水に分離 され，蒸気はタービンへ送られる。蒸気ドラムの中で は飽和水と給水系からの給水が混合し、下降管を通っ て再循環される。

電気出力は $165 \mathrm{MWe}$ で, 原子炉で発生させた尔気

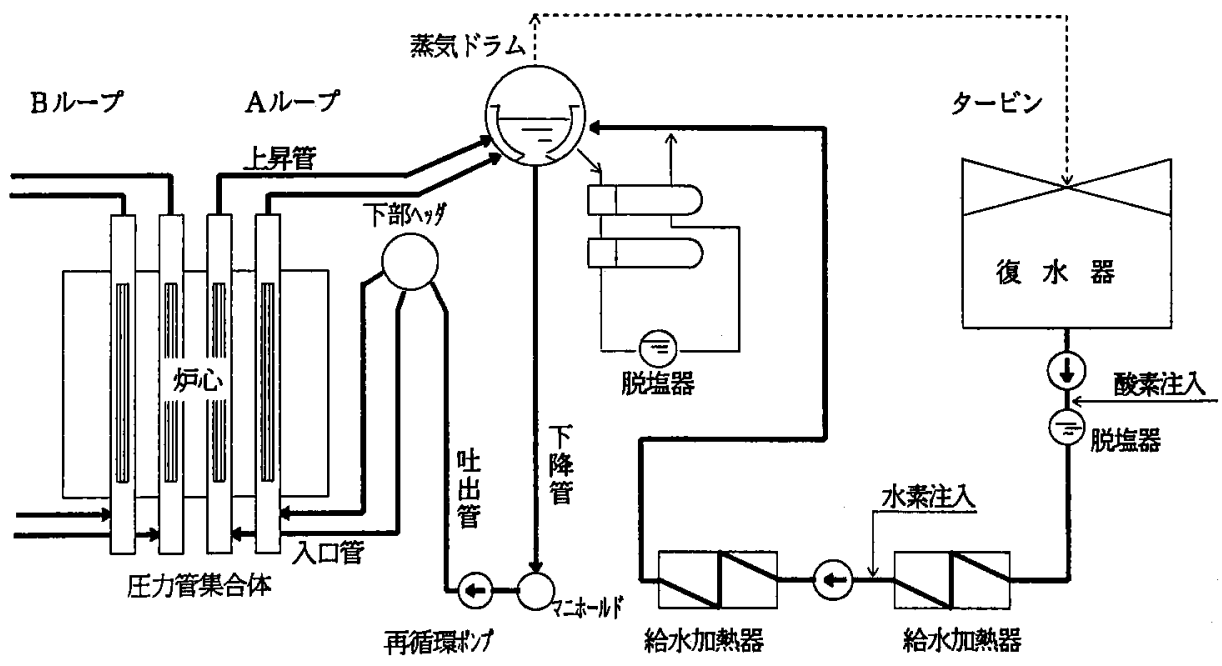

第 1-3(1) 图「ふげん」の概略系統因 


\section{2.「ふげん」における水化学管理技術}

「ふげん」の水化学管理は，減速材である重水と原子 炉冷却材の水質管理が主要なるのである。重水の管理 技術については，先行重水炉の経験(2) を参考にしてき たが，国内で初めての発電用重水炉であるため，重水 浄化系樹脂の性能低下対策等については独自に開発し てきた。

一方，原子炉冷却材の管理については，BWRの経 験をるとに水質管理を行い，放射線被曝の低減,然料 健全性の確保等を進めるとともに，原子炬冷却系に拈 けるSCC 発生予防対策と乙て沸騰水冷却型妒で国内 では初めて，炬水への水素注入を実施し，水質改善を 図っている。また，定期検査時の被曝低減のため， 1989年および91年には，供用期間中の原子力発電所と しては国内では初めて，原子炉冷却系統全体の系統化 学除染を実施し，大幅な被曝低隇に成功した。本項て は「ふげん」に括ける水素注入技術扣よび系統化学除染 技術について述べる。

\section{3.「ふげん」における水素注入技術}

1980年11月の計画停止時にSCCが発見されて以来, SUS 304 ステンレス鋼からなる原子炉再偱環系等の機 器·配管について SCC 発生を防止するため, SUS 316 系(低炭素)への材料取替, 配管溶接部の高周波加熱江 よる残留応力改善(IHSI)等の対策を計画的に実施して きた。しかしながら，管群構造となっている入口管と 上昇管については，接近性・作業性が悪く、これらの 対策の適用が困難であったことから水素注入法を適用 し，水質環境を改善することによって SCCの発生を防 止することとした。

水素注入の適用にあたり，1984年 7 月から にかけて短期水素注入試験を実施し，水素注入による 炉水溶存酸素濃度の低減効果，ブラント全体に及ぽす 波及効果を調查して安全に水素注入が行えることを確 認した(3)。また，低昰速度引張試験(以下SSRT)を 行い, SCCの発生を防止するのに十分な炉水溶存酸素 浱度を定めた。これと並行して水素注入による水質変 動の確認拉よびSUS 304 材の腐食電位測定を実施し た。その結果，給水中に水素を $1.5 \mathrm{ppm}$ 程度注入する ことにより，炉水中溶存酸素濃度を注入前の $80 \mathrm{ppb}$ ら $20 \mathrm{ppb}$ 以下まで低減させることができること，炉水 溶存酸素港 $30 \mathrm{ppb}$ 以下で鋭敏化SUS 304 材(粒界に 炭化物を析出させ，Cr久之層を有する材料)の IGSCC (校界型 SCC) 破面率 (全破面面程中下占的る IGSCC 面
皘の割合) 通常SSRTによる測定下限值とされてい る1\%以下まで低下し，さらに $10 \mathrm{ppb}$ 以下では全く IGSCCの発生は誌められなくなること, SUS 304 材の 腐食電位は，炉水の溶存酸素濃度 $10 \sim 15 \mathrm{ppb}$ でー250 〜-210 mV(SHE)の範囲にあり,この範囲内にIGSCC の発生が確認されなくなるしきい值が存在することを SSRTで明らかにした(3)。

短期水素注入試験の結果を踏まえ，1985年12月から 水電解方式の水素・酸素発生装置を用いて連続的な水 素注入を開始した。水素注入前の比較的酸化性の強い 環境下にあった然料を，水素濃度の高い環境下にさら すと然料被覆管材の水素吸収量が増大寸るといら文献 情報(4)に基つき，水素注入開始前に装荷されていた然 料が炉心から全部取り出された第 8 回定期検查(1989 年)までは，炉水中の溶存水素濃 度 と溶存酸素濃度の 比が15以下になるように管理した。この時の炉水溶存 酸素濃度は $15 \mathrm{ppb}$ 以下に維持された。第 8 回定期検査 以降は，この濃度比の制限を撒廃して，炉水中溶存酸 素濃度を $10 \mathrm{ppb}$ 以下となるように管理している(5)。

連続的な水素注入を開始してからの 5 年間に，炉水 中のイオン状の ${ }^{60} \mathrm{Co} の$ 濃度は, 第 耳-3(2) 図に示すよ らに，3年で的 2 倍の濃度に上昇したあと減少し始 め，5年後には水素注入前の濃度に復㷌した。 ${ }^{60} \mathrm{Co}$ 濃 度の上昇は，水素注入によって炉水の水質環境が還元 性に移行し，然料棒表面に付着している $\mathrm{Fe}$ 酸化物から $の^{00} \mathrm{Co}$ の溶解が若干加速されるためであると考えられ る。またこれによって原子炉冷却材と直接接触する 部分の Fe 酸化物中の ${ }^{60} \mathrm{Co}$ 濃度が低下寸るので, 一旦上 昇した冾却材中の ${ }^{60} \mathrm{Co}$ 濃度は再び低下し始めるものと 推定している。水素注入に伴らこの一時的な炉水中の ${ }^{60} \mathrm{Co}$ 濃度の上昇により，原子炉烚却系配管の線量当量 率は約15\%高い值になっているが，通常の定期検査に 係わる線量当量はほぼ横ばいであり, 線量当量率の上 䒜は，許容できる範囲内にあるるのと考劣られる。こ のはかの水質については，大きな変動は見られない。

\section{4.「ふげん」における系統除染技術}

給水への酸素注入, 復水脱塩器の運用改善など水質 管理面から原子炉冷却系配管等への放射性核種の蓄積 抑制対策を実施してきたが，蓄積量は運転時間ととる にゆるやかながら上昇している。このような状況下に あって，1989年度の第 8 回定期検査においては，Aル ープ側の再循環ポンプの分解点検就よびSCC 対策とし ての配管取替工事が計画され，また，1990年度にはB ループ側の同様な工事が計画され，それぞれの定期検 

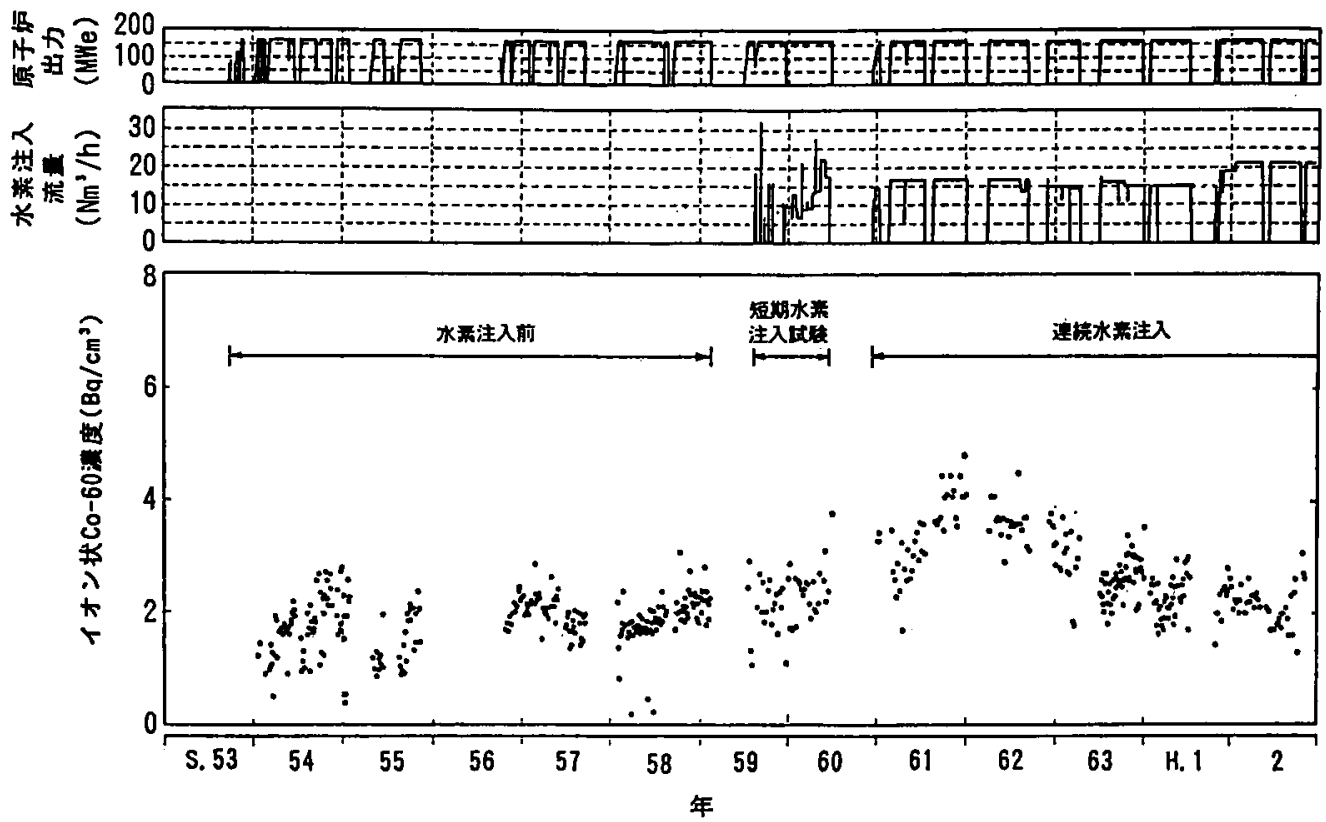

第 I-3(2)国水素注入に伴 5 炻水中 ${ }^{00} \mathrm{Co}$ 溇度变化

查にかかる総線量当量は10人 $\mathrm{Sv}$ を超える見込みとな った。そこで，これを㧕制することを目的として，10 年以上にわたって開発を進めてきた希薄液除染法によ る系統除染をそれぞれのループに適用した。

使用した除染㓮は, キレート系希薄液除染剤クリデ コン203(主成分：EDTA)であり，除染条件は，除染 剂濃度 $0.1 \%$ 以下，除染時間 $24 \mathrm{~h}$ ，除染温度 $120^{\circ} \mathrm{C}$ であ る。系統除染工程は, 昇温, 除染, 浄化, 浄化・フラッシ ングからり，除染工程に括いては除染中の系統の線 量当量率を低く抑えるために，除染液の一部を原子炉 冷却材浄化系の脱塩器で浄化しながら浄化によって失 われる除染剤を連続的に補給する䟻染中浄化法を考案 して採用した(6)。
この除染によって得られた除染保数は，第盲-3(1)表 に示すよらに，部位によって差異が見られたが，いず れる目標の 2 を上回った。定期検査時の総線量当量に おいては，AおよびBループの系統除染とす，系綡除 染を適用しない場合の予測值の約 $50 \%$ に低減すること ができた。た，薬注等の除染作業に係わる線量当量 除染中浄化法の採用により 0.1 人 Sv 以下に抑制する ことができた。

除染に伴う材料の健全性については，除染咅用前の 確認試験で問題のないことを確認しているが(7)(8)，実際 の除染下においてむ問題のないことを確認するため， 系統除染中に圧力管内に試験片を装着して，腐食量， SCC 感受性を調查した。結果はいずれる除染总用前

第 1-3(1) 表 系統 除染の結果

\begin{tabular}{|c|c|c|c|c|c|c|}
\hline \multirow{2}{*}{ 部 位 } & \multicolumn{3}{|c|}{$\begin{array}{l}\text { 第 } 8 \text { 回定期検查時の } \\
\text { Aループ系統除染 }\end{array}$} & \multicolumn{3}{|c|}{$\begin{array}{l}\text { 第 } 9 \text { 回定期検查時の } \\
\text { Bループ系統除染 }\end{array}$} \\
\hline & $\begin{array}{l}\text { 除染前 } \\
(\mathrm{mSv} / \mathrm{h})\end{array}$ & $\begin{array}{l}\text { 除染後 } \\
(\mathrm{mSv} / \mathrm{h})\end{array}$ & $\begin{array}{l}\text { 除染係数 } \\
(D F)\end{array}$ & $\begin{array}{l}\text { 除染前 } \\
(\mathrm{mSv} / \mathrm{h})\end{array}$ & $\begin{array}{l}\text { 除染後 } \\
(\mathrm{mSv} / \mathrm{h})\end{array}$ & $\begin{array}{c}\text { 除染係数 } \\
(D F)\end{array}$ \\
\hline 蒸気ドラム & 2.42 & 0.91 & 2.7 & 2.58 & 0.71 & 3.6 \\
\hline 下降管・吐出管 & 2.03 & 0.24 & 8.5 & 1.92 & 0.36 & 5.3 \\
\hline 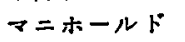 & 0.88 & 0.19 & 4.6 & 0.84 & 0.14 & 6.0 \\
\hline 再循環ポンプ & 1.11 & 0.17 & 6.5 & 1.11 & 0.23 & 4.8 \\
\hline 下部ヘッダ & 3.05 & 1.18 & 2.6 & 2.16 & 0.41 & 5.3 \\
\hline 入口管 & 5.78 & 2.41 & 2.4 & 4.28 & 1.19 & 3.6 \\
\hline 上昇管 & 5.93 & 0.96 & 6.2 & 4.31 & 0.37 & 11.6 \\
\hline
\end{tabular}

除染係数 $(D F)=$ 除染前の線量当量高/除染後の線量当量率 
の確認試験の結果と同等であり，また除染後の機器の 用放点検です異常は認められなかった(9)。

\section{一考文献—}

（1）明比道夫，川原敏夫：新型転换师「らげん」臨界10年と技術 成果, 原子力工業, 34[8]，7 18 (1988).

(2) JRR-2汇ける水・ガスの処理と分析, JAERI 1024, (1962).

(3) Nilzawa, T., Kitabata, T.: Proc, 4 th Int. Conf. on Water Chemistry of Nuclear Power Reactor Systems, Bournemouth, Vol. 2, D.75 (1986).

(4) $\operatorname{Cox}$ B.: Effect of hydrogen injection on hydrogen uptake by BWR fuel cladding, EPRI NP-3146, Final Rep. (1983).

(5) KIrabata, T., NaOI, Y., et al.: Proc. 1991 JAIF Int. Conf. on Water Chemistry in .Nuclear Power Plants, Fukui, Japan, p. 107.

（6）川崎 界，直井洋介，他：新型転换沪ふげん発電所におけ る原子炉椧却系の系統除染，(I )，(II )，原子力学会「1990 年会」要旨集, $\mathrm{J} 48,49$.

(7) Nakayama, H., et al.: Proc. 1988 JAIF Int. Conf. on Water Chemistry in Nuclear Power Plants. Tokyo, Japan, p. 449.

(8) KOIKE, M., et al.: Ref. (5), p. 716.

(9) NAOI, Y., KITABATA, T., et al.: ibid., p. 211.

\section{IV. 要素技術の開発}

\section{IV-1 BWRの水化学(1)}

郴東芝長尾博之, 日立制作所内田俊介

\section{1. 楾量低娍技術}

発電ブラント定検作業徒事者の放射線被曝線量を効 果的に低隇するには,プラント1次系の配管・機器の 内面に付着·蓄積する放射性の腐食生成物(CP)の量を 抑制し，作業場所周辺の放射線線量率を低減する必要 がある。このCPの学動についてすでに多くのことが 解明され，その結果に基ついて，種々の被曝低減対策 が立案されるとともに実機への適用が進められ，大き な成果が得られている。これらの対策技術の解説はす でいくつか見られるので(2)，本節では，これらのう ら水化学的観点から現在すな捈討・改良が加克られ つつある技術のいくつかについて紹介する。

\section{(1) 村料表面処理技街}

放射性CPの中で最も注目すべき ${ }^{80} \mathrm{Co}{ }^{58} \mathrm{Co}$ よ゙の放 射性C。の発生源として，炬心照射場にあるステンレ ス鋼やインコネルなどの重要性が指摘されているが， なかです然料集合体のスペーサの中の支持バネとして 用いられるインコネルX750は重要な発生源と考光ら れ，その表面を事前に酸化处理し，Co 放射能の溶出速 度を抑制する試みがなされている(3)。

すなわち，従来のオートクレーブ処理条件に対し， 空気中酸化処理を施せば，インコネル上により緻密な 酸化皮膜が形成され，高温水中での腐食に上る金属イ オンの溶出速度が抑制されることがわかった。生成し た酸化皮膜の化学形態の組成比を，皮膜の表面から金 属母材に至る深さ方向に対して測定した結果を第 N-1
(1)図に示す。高温空気酸化したインコネル試料(第 $\mathbb{N}-1$ (1)図(b))の酸化皮膜表面層の大部分は，溶解度の極め て低いニッケルフェライトで覆われ，その下層に高割 合の酸化 $\mathrm{Cr}(\mathbb{I I})$ 㬝が見られる。これらの 2 層が金属 母材の溶出速度の抑制に有効飞働いているものと考兄 られる。

(2) $\mathrm{Ni} / \mathrm{Fe}$ 比コントロール

給水から妒水へのFeクラッドの持込み量の低温対策 を完了した最近のプラント，いわゆる低クラッドブラ ントでは， $\mathrm{Fe}$ や $\mathrm{Co}$ の炬内举動が従来と著しく変化し ていることに注意する必要がある。この現象の詳しい 説明は既報(4) 江翼るが，種々調查の結果，炉水中の放 射性 Co の濃度を低下させるには，如井への $\mathrm{Fe}$ クラッ ドの持込み量を $\mathrm{Ni}$ イオンの持込み量の少なくとも 2 倍以上に保つ必要があることがかかった。最近の低ク ラッドブラントにはこの概念に基づいた $\mathrm{Ni} / \mathrm{Fe}$ 比コン トロール運転が採用されており，すべて良好な結果が 得られている。その具体的な方法として，特に最新の プラントでは, プラントの系外で生成・調整した Feク ラッドを給水系に連続注入する方法が採られている が，どのよらな化学形態捄よび形状の Fe クラッドが Ni扰よびCoのイオンと最む反応し易いがついてさ らに検討が進められている。

\section{(3) $\mathrm{Zn}$ 注入}

材料表面への放射能付着速度を抑制する方法の一つ として，米国GE社が $\mathrm{Zn}$ 注入法を開発した。この方法 は, 給水中に常時Znイオンを注入し，炉水中の Zn 1 オン濃度を10数 ppbに保っことによって，炉心外配管 材料内面の酸化皮膜中の格子欠䧩に $\mathrm{Zn}$ 原子を充㙂し， 皮膜の政密度を增加させて虐食速度を抑制し，放射能 の取込みを抑制しよらとするるのである。 


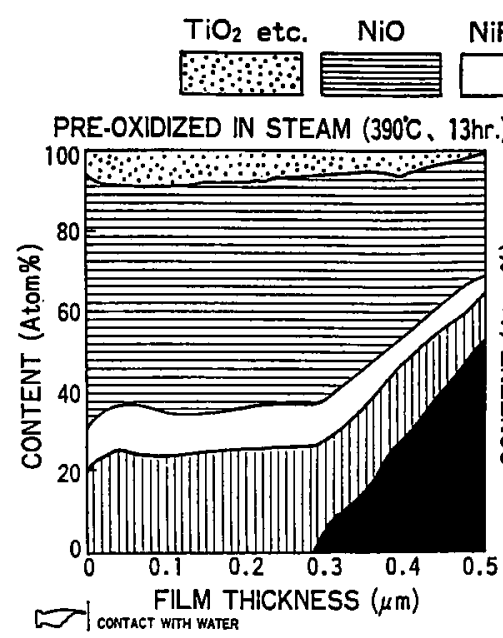

a) pre-oxidized in steam $\left(390^{\circ} \mathrm{C}, 13 \mathrm{hr}\right)$

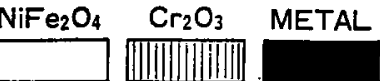

PREFILMED IN AIR $\left(700^{\circ} \mathrm{C}, 5 \mathrm{hr}.\right)$

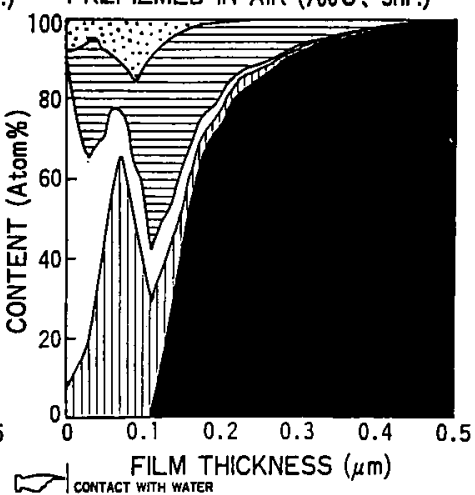

b) prefilmed in air $1700^{\circ} \mathrm{C}, 5 \mathrm{hr}$

第 N-1(1) 図 インコネルX750の腐食酸化皮膜の酸化物組成分布(3)

$\mathrm{Zn}$ 注入は1987年にホープクリークプラントにはじ めて導入されて以来, すでに6つの実働ブラントに適 用され，それぞれ程度の差は見られるすのの，その有 效性が実証されつつある(5)。なお，Zn注入法の現時点 に扮ける問題点は, ${ }^{85} \mathrm{Zn}$ 放射能が生成し, ${ }^{80} \mathrm{Co}$ の抑制 効果の一部を相殺してしまうことである。この点を改 善するため, ${ }^{65} \mathrm{Zn}$ の親核種である ${ }^{64} \mathrm{Zn}$ 同位体をできる たけ取り除いた Zn 元素の製造技術が開発されつつあ る。

\section{2. 腐食生戍物の除去技術}

給水系から炉水に持ら込まれる CPの量をできるだ け少なくすることが，被曝低減の観点からまずは必要 である。この目的に対しては, 復水浄化系に用いられ ている従来型の混床式脱塩塔のみでは不十分であるこ とがこれまでの経験からわかっている。復水浄化系の CP除去性能，特に除鉄性能の向上を図る方法として， 主として2つの方向から開発が進められた。1つは混 床式脱塩塔そのるのの除鉄性能を改善しようとするも ので，他の 1 つは，混床式脱塩荅の前段に除鉄用のフ ィルタを設置し, 復水浄化系全体として除鉄性能の向 上を図る二重式の復水浄化系とするるのである。

前者については，実機に使用されているイオン交換

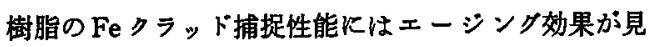
られることをとントに，ます樹脂の除鉄メカニズムに ついて詳細に検討された。その成果を基に，除鉄性能 に特に榎れていると予湘される樹脂を選択し，従来型 の楜脂と共に実譏の復水を用いてクラッドの除去性能
試験が行われた。結果を第 IV-1(2) 図に示す(6)。図中の 新ゲルタイブの樹脂が除鉄性能に優えるとして選択さ れた候補樹脂であるが，この樹脂床の出ロクラッド澧 度は, 2 週間の通水後も非常に低く, 増加傾向を示し ていない。他の改良樹脂に比べても著しく優れたクラ ッド除去特性を示している。今後, この樹脂の実機適 用性に関する評価研究が進められるるのと思われる。

後者については，粉末状イオン交換樹脂をブリニー トしたフィルタの設置が多くのブラントに採用され， 復水浄化系としての除鉄性能が飛躍的に向上したが, 粉末状イオン交換樹脂が放射性の 2 次廃乘物として器 生するため, これに代わる同等性能のフィルタの開発 が求められた。この要求を満足するすのとして中空米 膜フィルタ(HFF)システムが開発され，すでに幾つか のブラントに設置されて，極めて良好な状態で運転さ れている(n。

\section{3. 将来技術}

\section{（1）属食桭境の楥和技術}

原子炉の泠却水は，炉心で中性子， $\gamma$ 線の強い放射 線にさらされ, 分解して, $\mathrm{O}_{2}, \mathrm{H}_{2}$ などの安定な分子, $\mathrm{H}_{2} \mathrm{O}_{2}$ などの準安定分子, $\mathrm{O}_{2}-\mathrm{HO}_{2}-\mathrm{H}, \mathrm{OH}, \mathrm{HO}_{2}$ など のイオン,ラジカルを形成する。分解生成物のうち, 原子炉構造材の腐食に影䈏を与えるのは，主として $\mathrm{O}_{2}$ と $\mathrm{H}_{2} \mathrm{O}_{2}$ である(い。

水素注入による腐食緩和は，炉水に $\mathrm{H}_{\mathbf{2}}$ を添加する ことにより，(1)水の放射線分解自体の抑制，(2)生成し た $\mathrm{O}_{2}$ と $\mathrm{H}_{2} \mathrm{O}_{2}$ の $\mathrm{H}_{2}$ との再結合，の 2 通りのブロセスて 


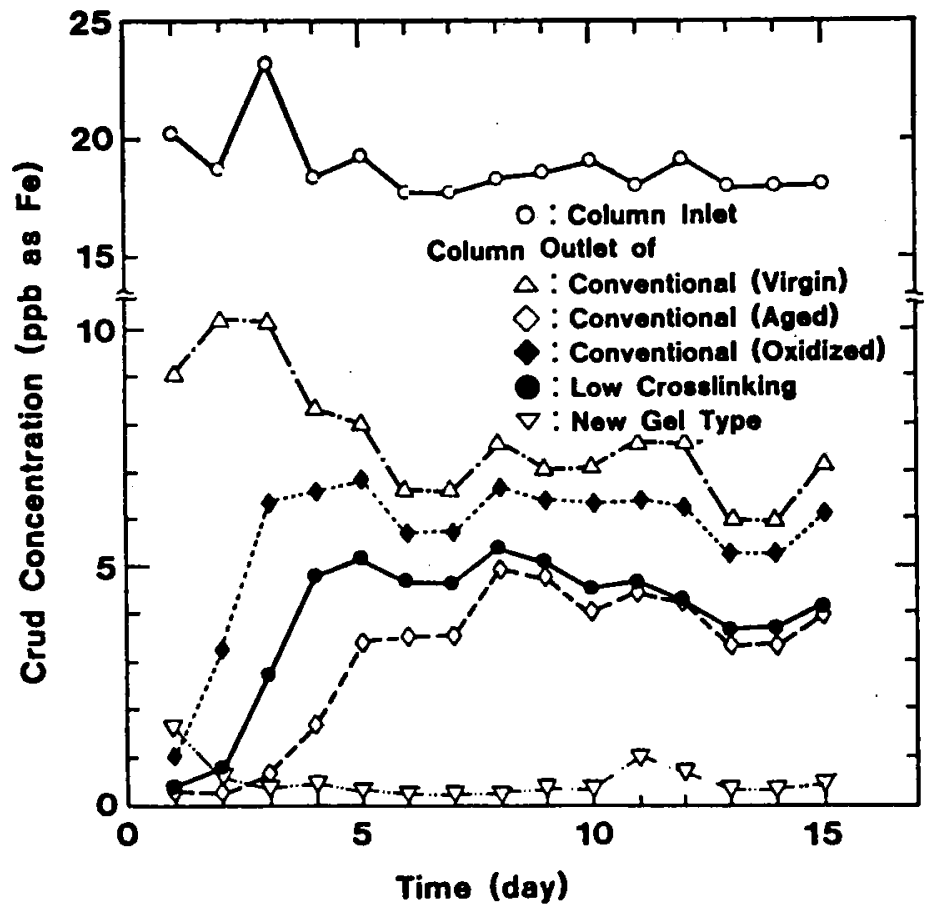

第 IV-1(2)图各種樹脂塔出口のクラッド湍度(の

$\mathrm{O}_{2}$ 浱度を低減して，腐食を抑制するるのである心。

第 $\mathrm{N}-1$ (3) 圈に，水素注入時の柜水 $\mathrm{O}_{2}$ 濃度の央測值を まとめる。横軸の実効炉心 $\mathrm{H}_{2}$ 濃度は, $\mathrm{H}_{2}$ 注入量/炉心 流量で定義されるもので, 师心入口の $\mathrm{H}_{2}$ 浱度には等 価で，炉心での水の放射線分解量を支配するパラメー タである。第 $\mathrm{IV}-1(3)$ 図の炉水 $\mathrm{O}_{2}$ 漕度はブラント間で のバラッキが大きいが，炉心での水の放射線分解量に
よって决まる主蒸気中の $\mathrm{O}_{2}$ 濃度は, プラントの差異に よらず，実效炉心 $\mathrm{H}_{2}$ 濃度の関数で整理できる(1)。

妒水中に生成した $\mathrm{O}_{2}$ は，主として $\mathrm{H}_{2}$ との再結合に より消失する。この再結合反応はダウンカマ部の線量 率に依存し，炬心周りの構造の差異により，第 $\mathrm{V}-1(3)$ 四に示すよらに，ブラント間で师水 $\mathrm{O}_{2}$ 丧度のバラッキ が大きくなる。また，この再結合反応はCu蛙イオンな
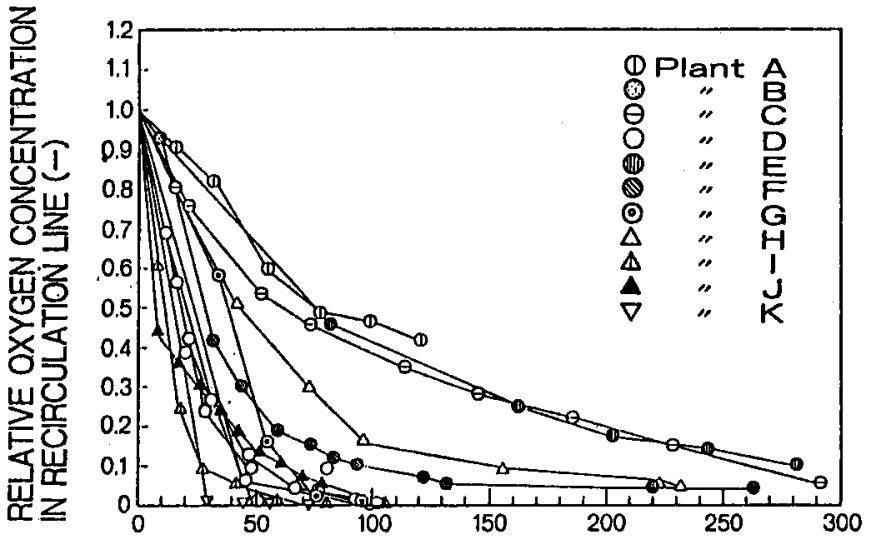

EFFECTIVE HYDROGEN CONCENTRATION (ppb)

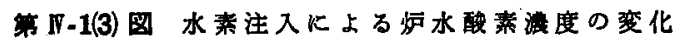


どの不純物にも影響され， $\mathrm{O}_{2}$ 瀑度は $\mathrm{Cu}^{2+}$ イオン瀑度 の高いプラントでは高く，Zn注入プラントでは低くな っている(1。

このよらな線量率，不純物などの影警を考虑して BWR 1 次冾却水の放射線分解举動を理論的に定量化 可能なモデルを完成し，炬水の $\mathrm{O}_{2}$ 浱度を窟食損侮が抑 制できるレベルKまで低減可能な $\mathrm{H}_{2}$ 注入量を予測する ことがでさた。このモデルで予測されるすら1つの重 要な結論は，1 次冷却系構造材の腐食を律速するのは $\mathrm{O}_{2}$ よりも，むしろ $\mathrm{H}_{2} \mathrm{O}_{2}$ である可能性を示唆した点であ る。現在，まだ $\mathrm{H}_{2} \mathrm{O}_{2}$ の分解定数の測定值の信頼性が そしく, 正確な証価は難しいが, 分解定数が過去のデ 一タに比べ下方修正されつつあり，一部プラントの 1 次冷却水中で, 予測通り $\mathrm{H}_{2} \mathrm{O}_{2}$ が検出され, $\mathrm{H}_{2} \mathrm{O}_{2}$ への 関心が高まりつつある(1。

水素注入による原子炬構造村の腐食損傷抑制は，ブ ラント長寿命化のキーテクノロジーとして期待されて

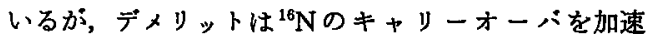
し、タービン線量率を增大させることにある。原子妒 で生成する ${ }^{10} \mathrm{~N} か ゙$ 水素注入により化学形態を揮発性の NO形態に変えることが原因と考えられているが，こ の事実は， ${ }^{10} \mathrm{~N} の$ 化学形態をらまく制御すれば，逆に BWRのタービン線量率を低減できる可能性を示唆し ているすので, 玩在, 理論と実験の両面から ${ }^{16} \mathrm{~N}$ の化 学形態制御の研究が進められており，今後の一層の発 展が期待される(1)。

（2）水算データによる冷却系機器の異常診断

原子炉冷却水を線量率の低減や構造材の長寿命化を 目的にした管理あるいは制御の対象のみでなく，重要 な情報云達媒体であると捉兄ると, 原子炍水化学の研 究は今後さらに新しい分野へ展開可能となる。

原子炬冷却水の水質变動から原子カブラントの運転 状態や構成機器の異常を早期に検知し, 対策すること は，基本的にはわれわれの血液や尿を検査することに よって，体に生じつつある異常を早期に検知し，治療 することによって重大な病気として䫒在化することを 防ぐ予防医学的な考光炕対応するものである(1。

BWRでの水質診断システムの研究開発動向は, 3 つ のフェーズ，すなわち，(1)オフラインデータによる診 断, (2)オンインデータによる診断, (3)人工知能(AI) 応用による診断，に分類できる(1。
フェーズ(1)のシステムのちち，水質データの収集， 分析など従来からのルーチンワークの自動化を主目的 とするすのは，国内でもすでに一部のブラントで央用 化されている。これに水質異常時の診断機能を付加し たものとして，水質変動と構成機器の異常とを関連付 けたマトリックスに基づいて機器の異常原因を診断し たり，放射能蓄積举動解析基ついて水質変動時の線 量率变化を予測評価するシステムも報告されている。

フェーズ(2のシステムでは, イオングロトグラフ を用いたオンラインの不純物データ採取装置と組み合 わせたシステムが報告されている。

フェーズ(3)のシステムは，办質管理の専門家の知識 を取り入れた高度な異常原因の診断と対応策ガイダン 又機能の実現を目指し，冷却水の水質変化からプラン 卜構成機器の異常を診断しょらとするるのである。

これまでの問題解決型から問題予湖，予防保全型へ と本化学技衍を高め，变換させようとの試みは，まだ 緒についたばかりであるが、プラントの水を制するも のがプラントを，特にプラントの信頼性を制すると の認識が高まりつつあることもまた事実である。今後 は，プラント化学の立場だけではなく，厷く材料機器 システムの研究者, 技術者と協力しつつ, 上記課題へ 北戦し，一日も早い実現を期待したい(い。

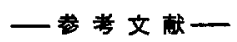

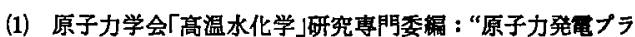
ントの水化学管理と基船技街”，(1991)。

（2）㑡克ば，石博頙吉，他：原子师の水化学-研究娚状と今後 の桜題，原子力脑，29[4]，273 (1987).

(3) Hemmi, Y., et al.: Passivation mechanism of oxide films formed on Inconel X750 in simulated BWR core environment, Water Chemistry 5, BNES, Vol. 2, p. 81 (1989).

(4) NAGAO, H., et al.: Corrosion product behavior in low crud boiling water reactors, Water Chemistry 4, BNES, Vol. 2, p. 59 (1986).

(5) WoOD, C.J., et al.: Experience with zinc injection passivation at BWR plants in the USA, Ref. (3), Vol. 1, p. 111.

(6) INAMI, I., et al.: Mechanism of crud removal by deep bed resins, Proc. 50 th Int. Water Conf., Pittsburgh, Penn., USA, p. 552 (1989).

(7) OBU, E., et al.: Operational experience of condensate polishing with hollow fiber filter on power plant, Proc. 51 st Int. Water Conf., Pittsburgh, Penn., USA, IWC-90-34, (1990). 


\section{IV-2 PWRの水化学}

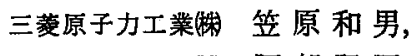

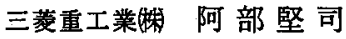

\section{1 次系}

(1) 楾源低減

発電ブラントの保守・点検作業に係わる作業員の被 曝低減において，線源低減は重要なフイテムである。 主要な線源である機器・配管内面の放射性CP’量を低減 する目的で，第 V-2(1)図に示すような対策が研究ある いは実機に採用されている。

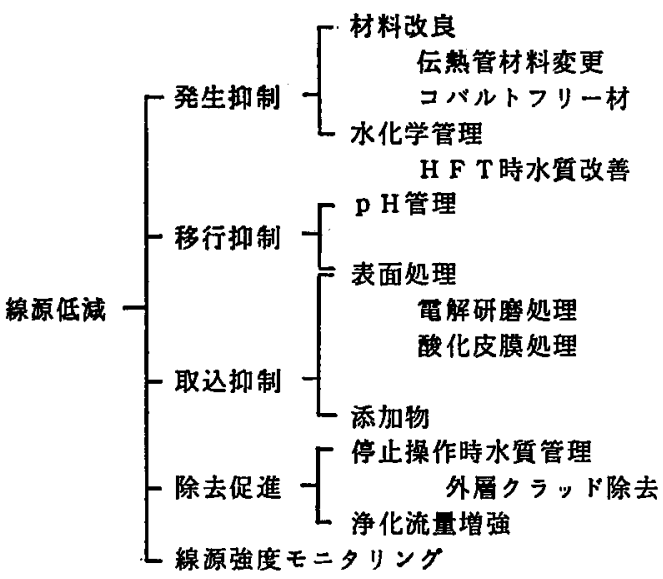

第 IV-2(1)图線源低隇対策

この中から我化学管理と密接に関係し，しかも実機 に適用された以下の 3 点の対策について概説する。

（1）温態機能試験(HFT)時の水質管理改善は, 従 来行われていた脱気純水あるいは脱気 Li 添加水 を $\mathrm{H}_{2}, \mathrm{Li}$ 添加水とするすのである。PWRでは核 然料の初装荷前にHFTとして1次冷却材を 300 C 近くに昇温し機器の試験が行われる。初 期腐食に相当するHFT期間の腐食率を抑制す ることは，核加熱後での放射性 CP の生成を低 減させる上で効果が大きい。1次系で最す接液 表面積の大きいSG卮熱管材(インコネル材)に ついて腐食試験が実施され， $\mathrm{H}_{2}$ と Li を添加し出 力運転時と同じ水質とすることが商切であるこ とが得られた。北海道電力侏泊 1 号機にて適用 され，初回定険時の線量当量率比較などから低 減効果が確認されている(1)。

(2) 出力運転時の冷却材 $\mathrm{pH}$ 管理は，世界的な検 討テーマとなっている。CPの溶解度の温度依
存性がpHに依存することから，高温である燃料 表面への析出を抑制し得る $\mathrm{pH}$ に管理しょうと するすのである。最近の溶解度データ(2)およひ 実機の実績(3)から，比較的高 $\mathrm{pH}$ 側とするのが よいとする考えが主流となっている。ただし， $\mathrm{pH}$ 調整剂である水酸化リチウムを現行の水質 仕様濃度 (2.2 ppm as Li)以上とすることによる 構成材料の健全性に対して充分な確認が望まれ ることから，原工陚(4)を含め種々の試験が継続 されている。

(3) 数日間に2 $2 \mathrm{~kg} の \mathrm{Ni}$ が浄化系で除去され る停止操作期間は，線源低減の上で重要であ る。実機に拉ける $\mathrm{Ni}$ の溶解挙動調查と実験に より，溶解・除去されている Ni は金属の化学形 態を持つCPであると推定されている。金属 $\mathrm{Ni}$ の溶解促進には溶存水素濃度を速やかに $1 \mathrm{cc} /$ $\mathrm{kg} \mathrm{H}_{2} \mathrm{O}$ 末満にすることが有効である。その手段 として $\mathrm{H}_{2} \mathrm{O}_{2}$ 添加による溶存水素濃度低下操作 が実機で実施され，Ni と放射性Coの溶解が促 進されることが確認された(5)。

今後は，クラッド状成分の移行抑制(6) と酸化皮膜中 への放射性 CP の取込 み抑制が，1次系水化学管理改 善検討の重要なテーマと考皃られる。

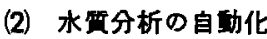

1 次系水質管理は，如心反度度制御材として添加さ れているホウ素(B)濃度の管理,構成材料の腐食抑制 のための不純物濃度と添加薬品濃度の制 御, 発電所の 作業從事者の放射線被曝をできるだけ低く抑えるため の適切な水質の維持を目的として行われる。水質管理 項目としては, $\mathrm{pH}$, 導電率, $\mathrm{B}, \mathrm{Li}$, 溶存酸素, 溶存水素, 塩化物イオン,フッ化物イオン,濁度があるが，これら はこれまでほとんど手分析に頼ってきた。原子炉の水 質分析の自動化は他の産業に比べて遅れているのが実 情である。これは測定対象である冷却材中に放射性物 質が含まれており，環境放出防止の観点から無漏沂化 が要求されることによる。また，分析廃液の軽減化の 観点から，測定用の試薬を添加することなく分析て き，分析後のサンブル水は元に㞍せることが理想的て ある。この要求を満足するには分析法そのものる限定 される。

最近では，分析の省力化やデータ妈理システムの適 用といら観点から，分析の自動化の要求が年々高まっ てきており，徐々に自動計器の導入が図られてきてい る。すでに，夷機ブラントに適用された自動計器とし $\tau \mathrm{pH}$ 計,電気伀導度計，溶存水素計がある。ホウ案計 
す実機に導入され，それなりの成果が得られているが す5少し精度向上が望まれ，一層の改良研究が進めら れている。溶存酸索計, 㯰度計は適用可能であるがま だ採用実積はない。

Li户塩化物イオン等の陰イオン不純物には,種々分 析法はあるものの，オンラインで無処理のまま直接分 析できる適当な計器がなく，今後の開発が望まれる。

（3）水程診断システム

水質管理でデータ処理と水質診断は重要な役割であ る。特に水質彭断は専門知識と経験が要求される。こ れをエキスパートシステムにより処理し，水貿異常の 早期検出と対策方法を示すことによって管理の高度化 が図れる。システムとしては，分析の自動化,データ の自動処理から診断までを一体化することが最終ゴー ルとなる。現在は，実績/知識をすとに基本的な診断 ロショクの作成による水質管理支援システムの構築が 進められてきている。しかし，前述のよらに分析の自 動化が完全でないため，分析值は手入力に頼らざるを 得ない状況にある。な找，水管理技術は年々高度化し ているため，それに応じて逐次，システムの改善が要 求される。

\section{(4) 今後の課㩆}

水質管理が目的とするプラントの健全性確保と被曝 線源低隇をより高度化するには，そのための理論の構 筑とその成果を実機に適用する技術の開発が必要であ る。したがって，今後は理論構築の実験技術に最新技 術である新素材や表面分析技術等の活用を図るととも に，実機への応用技術としては新しいモ二タ技術の開 発と適用が重要と思われる。

\section{2 次系}

\section{(1) 2 次系系㿠の概要と水留管理の考え方}

2 次系の系統構成は火力のあのとほとんど同じであ るが，厷熱管外面蒸発，䭒和弥気であるためタービン 系で大量のドレンが発生(脱気器一回収)，電気出力あ たりの系統容量・流量が大きいこと等の異なる点があ る。

2次系の系統構成材料は，SGの层熱管材(インコネ ル600,インコネル690,まだイッ舷ではインコロイ 800)を除いては注とんど火力のそれと同じである。こ のSGは，火力とは根本的に異なる㹂型U字管式熱交 換器で，层熱管は炭素鋼あるいはステンレス銅媻の管 支持板により支えられている。このため，管支持板管 穴と伝熱管の間に怗䘓な間隙(クレピス)が存在しこ の部分では，管外蒸発面の熱流動条件が他とは異な
り，缶水中の不純物等が混樎して，極端な場合は席食を 引き起こす可能性があるため, PWRの2次系水質仕 様は超臨界圧の火力プラントのそれと同等またはそれ より敛しいすのとなっている。このような背景から， 2 次系水質管理目的は基本的に次のように整理され る。

第 1 は，SGあるいはタービンでの局部的な不純物

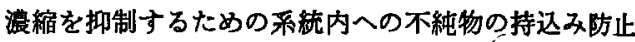
であり，第 2 は，系統構成機器·配管等の腐食防止であ る。これは各機器の健全性維持の面からのみならず, SGへの不純物(腐食生成物等)の持込み・堆皘低隇の観 点からす重要であり，具体例とてて水処理薬品による $\mathrm{pH}$ コントロール, 脱酸菜・還元性突囲気の維持強化, 持ち込まれた不純物等の除去に付いては，復水脱塩装 直(コンデミ)の設直・残留非再生樹脂のコントロール によるモル比管理/遊崔アルカリ生成防止を含む適正 運用, 脱気器による溶存酸素の除去がある。

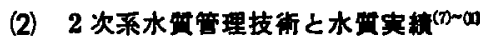

前項で述べた水質管理目標を達成するためのより具 体的な管理技術とその実綪を以下にをとめる。

（1）不純物低減

2次系水質の向上には，運用面でけでなく，適正な 施工管理,設 備面での改善・改良・信頼性向上等の対策 が必要である。

(1) 系統内への不純物持込みの防止

我が国のプラントは，すべて海水を復水器の冷却水 に用いているため，復水器からの海水漏洩は即不純物 の持込みとなる。このため，建設時の施工管理はもと より建設後, 定期検查時の復水冾却管の全数非破壤検 查・点検等によりその信頼性の維持に努めている。ま た，材料面です最近ではTi管の採用等により信頼性の 強化向上を計られている。

それです復水器で海水漏油が生じた場合は, 復水器 ホットウェルのカチオン龟気伝導度検出システムによ り速やかに検知し，その程度によっては隔離・補修が 行われる。その他, 復水器を含み真空系への空気の漏 洩す不純物・酸素の持込み源となるため，シール等の 対策が採用されている。

（2）系統内からの不純物の除去

建設・起動時あるいは定検時に系梳内に持ら込まれ た異物・不純物の除去のためには起動時のクリーンフ ップが重要である。これは大きく2つの段階に分けら れる。(1)起動前に最大給水流量の25\%以上で行ら全系 統再循㼈クリーンフップと(2)併入後の不純物の多い初 期ドレンの系外排出だよび復水器への回収・コンデ ミ 
による净化である。また，運転時に系統内で発生した 腐食生成物・持ち込まれた不純物等の除去に最子有効 な方法はコンデミの設置であり，溶存酸素の除去には 脱気器の設置・眖酸放の添加が有効である。わが国で はコンデミの設監が一般的で，すべて全量通水型また は部分通水型の深床式コンデミが設置されている。こ れらは，海外で $\mathrm{NH}_{3}-\mathrm{OH}$ 型の樹脂の使用例むあるか， 検討の結果Naリークの起こる可能性が大きいため, わが国ではH-OH型の樹脂を採用している。

(3) コンデミ

前述のよらに，2次系の水質管理にはコンデミが有 用な役割を果して括り，必要不可欠なるのであり，初 期ドレンの復水器への回収時にはほとんとの不純物が コンデミにより埩化される。第IV-2(1) 表に，代表的な コンデミの仕様と処理隶質を示す。

第 IV-2(1) 表 コンデミの仕粎

\begin{tabular}{|c|c|}
\hline 項 目 & 仕 様 \\
\hline 型 式 & $\begin{array}{c}\text { 深床式全量通水型 (14プラント) } \\
\quad " \text { 部分通水型 (4プラント) }\end{array}$ \\
\hline 連軽 & 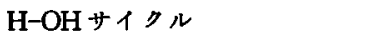 \\
\hline 定体積 & $120,000 \sim 220,000 \mathrm{~m}^{2}(10 \sim 30$ 日 $)$ \\
\hline 再生剤 & $\mathrm{HCl} / \mathrm{NaOH}$ \\
\hline 再生法 & 塔外分離再生(中間樹脂抜取) \\
\hline 処理水質 & 電気伝導率 : $0.06 \mu \mathrm{s} / \mathrm{cm}$ \\
\hline & $: 0.01 \mathrm{ppb}$ \\
\hline & $: 0.03 \mathrm{ppb}$ \\
\hline
\end{tabular}

(2) 2 次系構成機器の腐食抑制(11)

系統構成機器の接液部には種々の材料が用いられて おり，おの拉のの運転条件下で腐食を抑制することが 大切である。特に腐食による機器の機能劣化，それに 伴ら不純物等の系内侵入・堆積抑制の観点から， $\mathrm{Fe}$ ， $\mathrm{Cu}, \mathrm{Ni}$ の溶出を低減する必要がある。

(1) $\mathrm{pH}$ ヌントロール

系統構成材料の腐食抑制の方法の1 つは給・復水の $\mathrm{pH}$ ニントロールである。実際的には，水質管理仕様 を基に系綪構成材料・ブラント運用等を総合的に勘案 して実運用の基準が決められる。1例として揮発性薬 品処理(AVT)を採用しているプラントで $\mathrm{pH}$ (電気伝

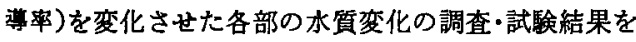
第 V-2(2) 图に示す。これからここのブンント最適 $\mathrm{pH}$ は, 復水冷却管(銅合金)の健 全性維持の面から， 銅の溶出が増える手前の 9.2(25元)と判断された。

(2) ヒドラジン

系統構成材料の腐食抑制の方法のも51 つは酸素濃 度の低減，すなわら酸化性㞣囲気の抑制である。この

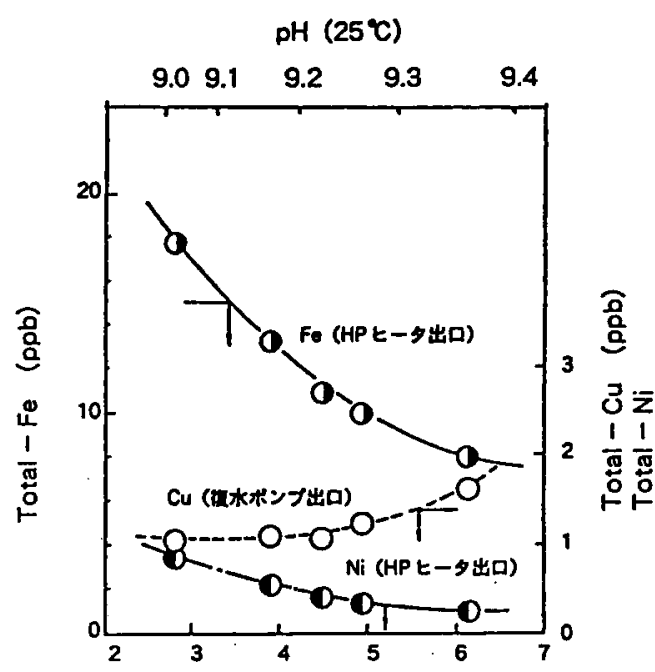

秴水政気伝望案 $\left(\mu \mathrm{S} / \mathrm{cm} \cdot 25^{\circ} \mathrm{C}\right)$

第 $\mathrm{V}-2$ (2)图 給水 $\mathrm{pH}$ (電気伝導率) と $\mathrm{Fe}, \mathrm{Cu}, \mathrm{Ni}$ 挙動

ため, 復水器・脱気器による物理的な脱酸素と併わせ て脱酸素㓮としてヒドラシンを添加する。ヒドラジン は脱酸素剤として働くが，残留ヒドラシンそれ自身が 還元性を高める腐食抑制剂としてる機能するため，溶 存酸素当量より多く添加することを基本としている。

（3） 2 次系水墭の現状

前述の水質管理技術の実施により，プラントの水質 は極めて清浄である。以下に主として不純物を中心に 記す。

(1) 起 動 時(9)00

起動器の不純物举動の指標の 1 つして SG内水の 水質が注目されるが，最近のブラントは全量通水，部 分通水コンデミ設置ブラントともK $\mathrm{Na}^{+}, \mathrm{Cl}^{-}$とも 10 $\mathrm{ppb}$ 程度，またSO4${ }^{2-} て ゙ 50 \mathrm{ppb}$ 程度で顕著な不純物の持 込みは認められらていない。

\section{(2) 定常運転時}

最近の数サイクルのSG内水の定常運転時の不純物 $(\mathrm{Na}, \mathrm{Cl})$ 濃度は各プラントとも $1 \mathrm{ppb}$ 前後と極めて清 浄で安定して捄り，問題ない值で管理運用されている。

(3) 停止時(12)

停止時に SG内の不純物のハイドアウトリターン （HOR，熱負荷の上昇によって析出した不純物が熱負 荷あるいは温度の低下によって再溶出する現象)濃度 を調查し，その結果から運転中のクレビス内不純物灙

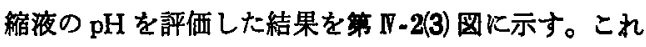


から運転中のクレビス内不純物量は比較的少なく， たpHも 4〜8の間にあり，ほぼ高温での中性域近傍 にあると考觉られる。

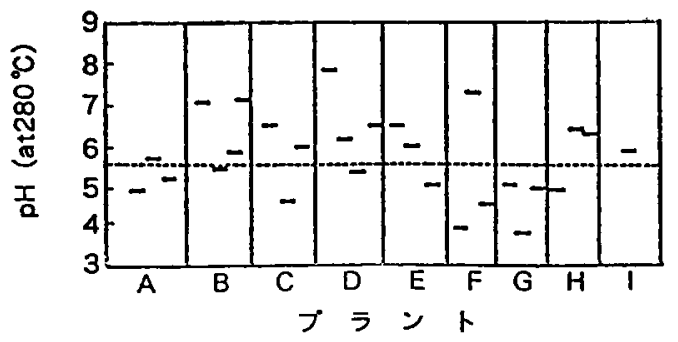

第 N-2(3) 图 HOR調查結果に上る運転中 クレビス部 $\mathrm{pH}$ の評価結果

\section{(4) 最近の不具合とその対策}

(1) 粒界損傷 (IGA)(7)(8)(18)(14)

初期のリン酸塩処理からAVTに切り替えた後, 減 肉損傷は大きく低減したが，その後いくつかのプラン トの SGでクレビス部のインコネル600製の公熱管飞 IGAが認められた。この原因を種々調査・研究の結果, 強アルカリ環境下 ( $300 \mathrm{C} C \mathrm{pH}=10$ 程度以上)の酸化性 雾囲気でIGA感受性が高いことが認められた。このた め，基本的対策として(1)遊離フルカリの持込み/生成 防止お上び(2)還元性雾囲気の強化を実施している。

主な対策実施事項は, 前述のコンデミの再生方法の 改善,アルカリ中和効果と耐食性被膜形成効果を考虑 したホウ酸注入, 還元性雾囲気強化のための高ヒドラ シン運転等である。

(2) スラッジ低減(8)(15)

スラッジ自体は，腐食值接関与せず必ずしも緊急 の問題ではないが，系統構成材のCPは運転時間が延 びるにつれて徐々に 2 次系機器へのスケール付着(例 えばポンプの羽根，ノズル，伝熱管表面等)によりポン フ振動, 差圧上昇等の不具合に，また最終的にはSGに 搬入され，スラッジ推積による新たなクレビスの形成 につながる可能性を持っているため，付着メカニズム 究明,エローション・コローション低隇(高 $\mathrm{pH}$ (フンモ ニフ）処理，モルフォリン処理等)の検討・対策が進めら れている。

(3) 化学洗浄 ${ }^{(17)}$

SG 2 次側の化学洗浄は, SG管板上飞強固に残留し ているスラッジあるいはクレビス部を埋めているスラ ッシ/スケール等を除去するために国内外で検討され てきたわが国です最近，広い意味でSG 2 次側㻴境 改善を図るため, 部分的な化学洗浄が美浜 1 号機, 大
飯 1 号機で実施された。

(4) 将来技術

プラントの煡全性を維持·管理して行く上で,ブラ ント全体の水化学状況の把握，それ基つく状況の馀 断・予測が，また SGの健 全性を維持·管理して行く上 では,クレビス部の環境モ二タに基づく状況の診断・予 測が望まれる。これらの状況の概要を炊化記す。

(1) 水質監視・唁断システム(9)(17)

多岐にわたるブラント各部の水質情報を自動·連続 的江集中監視し，必要な処理・解析・異常診断等を行5 総合的なッールは水質管理技術を一歩進めるすのであ る。このシステムの開発はメーカーですでに完了して いるが，実機への適用は前处理的データ处理システム のみて，総合システムの普及はまだであり，今後の発 展・普及が期待される。

(2) クレビス環境モニタリンダシステム(9)

運転中のクレビス部の化学環境をリアルタイムでモ こタすることは，HOR浱度またはバルク水水質から 濃維モデルを用いて計算・評価することと比へて，水 質管理上より確かな情報をるたらす。モ二か手法とし ては，実機水を直接導入するモデルボイラに同様なク レビス部を設け，高温 $\mathrm{pH}$ センを取り付ける方法と クレビス内の漫縮液を直線サンプリングする方法があ る。これらのらち，前者は実機で試験中であり，後者 は模擬ループで試験中である。後者の結果の 1 例を

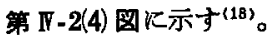

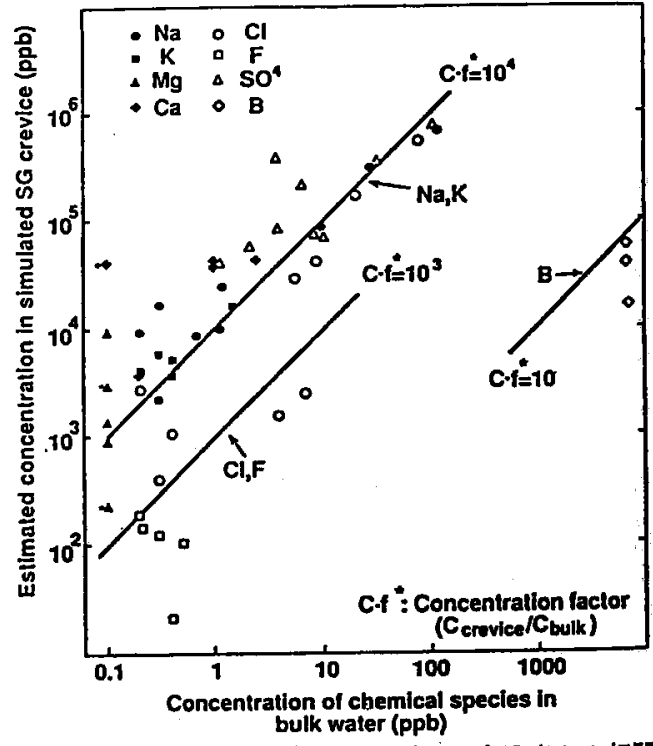

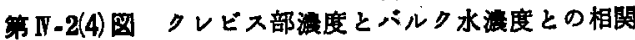




\section{(5) あとがき}

以上，2次系水質管理は系統の健 全性の維持のた め，系統の腐食防止·不純物の徹底排除を目指して努 力をしてきている。これらの結果として，わが国の 2 次系水筫は世界のトッブを走っているが，今啳はこれ に加党て，クレビス現境モニタリングをる組み込ん だより総合的な水質管理·䜪断システムの開発・実機 適用により，本質管理面での一層の発展が期待される。

\section{一考文堿—}

(1) Yamada, E., et al.: Proc. 1991 JAIF Int. Conf. on Water Chemistry in Nuclear Power Plants, p. 151.

(2) MIZUSAKI, H., et al.: ibid., p. 599.

(3) Hudson, M.J.B., et al.: Water Chemistry of Nuclear Reactor Systems 5, BNES, Vol. 2, p. 7 (1989).

(4) ABE, K., et al.: Ref. (1), p. 377.

(5) TAwAKI, S., et al.: ibid., p. 168.

(6) Kasahara, K., et al.: ibid., p. 303.

(7) 阿部堅司：PWRK和ける水化学，原子力工業，33[4], 32 (1987).

(8) ISHIGURE, K., et al.: Water chemistry experience of nuclear power plant in Japan, J. Nucl. Sci. Technol., 26[1], 145 (1989).

（9）原子力学会「高温水化学」研究専門委䋧：“原子力発電プラ ントの水化学管理と基盤技䔞”, p.117 (1991).

(10) HattoRI, T., Proc. Steam Generator and Heat Excanger Conf., (1990).

(11) Dor, M., et al.: Ref. (3), (1980).

(12) MrYazaKI, S., et al.: Proc.' 1988 JAIF Int. Conf. on Water Chemistry in Nuclear Power Plants, p. 132.

(13) KISHIDA, A., et al.: Proc. 3 rd Int. Symp. on Enviromental Degradation of Materials, p 132 (1987).

(14) TAKAMATSU, H., et al.: IGA/IGSCC Propagation behaviors of alloy 600, Proc. 4th Int. Symp. on the Enviromental Degradation on Materials in Nuclear Power Systems, p. 7-29 (1989).

(15) NAKAmURA, T., et al.: Ref. (1), p. 121.

(16) MIYAZAKI, Y., et al.: ibid., p. 223.

(17) YamaUCHI, S.: Ref. (3).

(18) ONIMURA, K., et al.: Operating experience with steam generator water chemistry in Japanese PWR plants, Proc. CSNI/UNIPEDE Specialist Mtg. on Operating Experience with Steam Generators, R 3-4 (1991).

\section{$\nabla$. 水化学技術の将来展望}

日本原子力研究所 立川 圓 造

水化学技術は，冷却水と材料との相互作用を取り报 5基盤技術の一つである。1960年代後半から，米国を 中心に BWR 配管，特に一部のステンレス鋼配管の SCC, PWR での蒸気発生器の腐食儿伴う種々トラブル の㩆在化, さらに怍業者被曝の增大の問題以来, 水 化学に関する研究が活発に行われてきた。れらの研 究では，材料因子とともに，材料の健全性炕及注す水 理境因子の重要性が指摘された(1)て(ら)。BWRにおいて

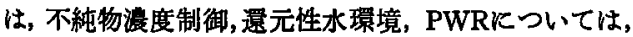
添加物制御， $\mathrm{pH}$ コントロール等，種々水化学管理方法 の改善により高温水中での村料扈食の抑制を図るとと br，1 次系構成材料中の Co 涨度の低減，代替枋の開 発,さらには净化系の強化などにより，大幅な被曝抑 制に大いに貢献した。これらに共通することは水質管 理の重要性である。

現在，水化学技術の関心事あるいは取り組むべき 課遁として，放射線線量率の低隇,フララントの長寿命 化(の，放射性婼率物の低減化等がある。これまでのよ らK，生した問題を解決することが主体であった問題 㧱決型の対応のみならず，これからは，将来にわたる 閔題予澌，予防保全を図ることが必要である。このた
めには，適切なモニタリングによる正確な状況把握， 種々データベース等の整備, データの評価・解析能力の 向上が不可欠である。これらをもとに，上り徶密な水 質管理が要求される。これには, ハード・ソフトの両 面からの技術開発が必要である。

昨年福井県で開催された「水化学'91」国際会墥(わ) おいても，水化学技術の今後の動向を示唆するすのと して，新材料，モニタリング,診断・エキスパートシス テムについての多数の発表があった。

材料については，セラミックス扰よびュバルトフリ 一耐摩耗材の検討のみならず，照射に上る鋼の劣化機 構についての報告等, 一ードおよびンフト面での報告 があった。

モニタリングについては、これまでに高温インラィ ンモニタとして, $\mathrm{pH}$ 計，腐食奄位計，酸素計，電気云䓕 度計等の開発例の報告があるが，今回新たに過酸化水 素と酸素を区別するセンサーの開発，さらにはPWR 1 次系での $\mathrm{pH}$ 二タの使用データの報告等があっ た。

钐断・エキスバートシステムについては，冷却村净 化設㣁の性能評価, 冷却水成分異常検知と猃断システ 
ム,SG予防保全システム等, 5 件の報告があった。い ずれも実機への適用には，さらに多くの改良の余地が あるものの，着実進展しており今後発展が望まれ る。

水質管理の基準の基となるデータべースについてみ ると，材料の腐食怙よび腐食に伴らクラッドの発生と 移行挙動に関する理解は必ずしも十分ではなく，現状 での経験をる踏まえた理解のもとで最適条件を設定し ている面が多々ある。例えば，高 $\mathrm{pH}$ 運転についてみ ると，被曝低減に有効であることは基礎データおよび 実機への適用例からも十分理解されているか，村料の 健全泩に与える影留に関するデータは必ずしも十分で はない。

また近年，冷却水中微量カチォン不純物のみなら

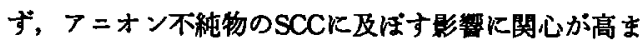
っているが,これらアニオン種の種類扣よびそれらの 浱度と影響の関連などについての定量的データは十分 ではない。この種の課題は, 然料表面でのクラッド付
着・再放出，さらには配管表面への取込み過程, 高温材 料の放射線誘起腐食とそれに及洼す水質の効果などに ついて同様㑧在する。

この種の問題に対しては，熱力学データ、コロイド． 界面化学, 放射線化学, 電気化学等の十分な基礎研究デ 一タが必要でありこれまで以上に産・学・官の一層の 連㩲のもと，実機データの詳細な調查はるちろんのこ と，実験室規模での地道な研究を推し進めることが必 要である。

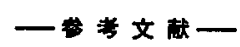

(1) 石博㩆吉：原子力工業, 34[11], 9 (1988)

(2) 長尾博之: 同 上, 34[11]，14 (1988).

（3）中島宣雄：同 上, 34[11]，22 (1988).

(4) 内田俊介: 同上, 33[4], 15 (1988).

(5) PICK, M.E.: Nucl. Energy, 26[2], 65 (1987).

(6) LESURF, L.E.: Proc. JAIF Int. Conf. on Water Chemistry in Nuclear Power Plants, Tokyo, Vol. 2, p. 575 (1988).

(7) Proc. 1991 JAIF Int. Conf. on Water Chemistry in Nuclear Power Plants, Fukui, (1991).

\section{论原子力発電プラントの水化学管理と基盤技術认}

\section{「高温水化学」研究専門委員会成果報告書}

\section{1年 8 月発行(限定出版) 好評発売中}

A 4 判オフセット印刷, 約 270 面, 予価(会員)4,000円;(一般)5,000円， Т 360 円 ○ご希望の方は学会事務局へ。(10部以上まとまれば送費サービス)

「高温水化学」研究専門委員会は，1987年 4 月から91年 3 月まで 4 年間にわたり，わが国の原 子力発電プラントの水化学面での運転実績扣よび水化学管理の要素技術や，その基礎となる考 え方などについて調查研究を行なってきた。

本報告書は 4 年間の調查研究を基とし，新たなデータも加えて書き下ろしたるのである。こ の分野に打ける最新の情報が盛り込まれて招り，今後の研究開発の動向を知り，現場での運転 管理を行う上で，極めて有用であるものと期待される。（詳細は「本誌」,33[8],806(1991)参照） 